\title{
Simultaneous administration of coffee and rasagiline/L-dopa protects against paraquat-induced neurochemical and motor behavior impairments in vivo
}

\author{
Mona E. Aboutabl ${ }^{1 *}$ (D), Asmaa M. Salman ${ }^{1}$, Amina A. Gamal el Din² and Yousreya A. Maklad
}

\begin{abstract}
Background: Caffeine is a natural alkaloid present in a variety of highly consumed popular drinks such as coffee, tea and soft drinks as well as chocolate. Its consumption elicits beneficiary psychostimulant that has been linked to a reduced risk of developing Parkinson's disease (PD). The aim of the present study is to investigate the possible synergistic neuroprotective effects of co-administration of caffeine (CAF) or coffee (COF) with rasagiline (R) or L-dopa against paraquat $(\mathrm{PQ})$-induced neurochemical and motor behavior impairments in mice.

Results: In behavioral tests, R + COF increased the locomotor activity in rotarod test compared to L-dopa + COF. L-Dopa combinations decreased the immobility time in FST compared to rasagiline combinations; L-dopa + CAF provided a similar increase in locomotor activity compared to R + CAF. Combination of CAF or COF with L-dopa or rasagiline resulted in a substantial improvement in brain neurotransmitter and antioxidant levels as they significantly increased dopamine and super oxide dismutase but significantly decreased nitric oxide levels as compared to L-dopa or rasagiline, respectively. Furthermore, they also exerted a protective effect against the neurodegenerative histopathological changes induced by PQ.

Conclusions: Our findings demonstrated co-administration of COF or CAF, adenosine 2A receptor antagonists, along with L-dopa or rasagiline possesses a new therapeutic strategy for the management of PD neurochemical disturbances and motor behavior impairments through preservation of the brain dopamine and serotonin content, antioxidants level and histological features.
\end{abstract}

Keywords: Parkinson's disease, Paraquat, Coffee, Rasagiline, Caffeine, Neurochemical disturbances, Motor impairments, Behavior tests

\section{Background}

Parkinson's disease (PD) is one of the most common neurodegenerative diseases, for which currently there is no cure. It affects more than $1 \%$ in elderly population (Ikawa

\footnotetext{
*Correspondence: monaaboutabl@gmail.com

${ }^{1}$ Medicinal and Pharmaceutical Chemistry Department (Pharmacology Group), Pharmaceutical and Drug Industries Research Institute, National Research Centre (ID: 60014618), 33 El Bohouth St., P.O. 12622, Dokki, Giza, Egypt

Full list of author information is available at the end of the article
}

et al. 2020). PD develops as a result of progressive loss of dopaminergic neurons in the substantia nigra (SN), leading to striatal dopamine (DA) depletion. This neurological condition caused by the degeneration of dopaminergic nigrostriatal system is largely responsible for the classical clinical motor symptoms including bradykinesia, muscle rigidity, tremor at rest and postural instability (Pires et al. 2017). In addition, non-dopaminergic degeneration also occurs in other brain areas which appears to be responsible for a suite of other non-motor symptoms such as anosmia, depressed mood, psychosis, emotional 
and cognitive deficits, sensory disturbances and pain, sleep disorder, autonomic, gastrointestinal and sensory dysfunction that precede the classical motor symptoms in $\mathrm{PD}$ and also recognized as relevant symptoms in PD patients (Hirao et al. 2015; Olanow et al. 2009).

Despite several familial forms of PD associated with specific genetic mutations, the majority of patients suffer from idiopathic PD (De Deurwaerdère et al. 2017). The etiology of the disease is not completely understood. The underlying molecular pathogenesis involves several pathways and mechanisms such as oxidative stress, $\alpha$-synuclein proteostasis, calcium homeostasis, neuroinflammation, mitochondrial function and axonal transport (Poewe et al. 2017).

Paraquat (PQ) (1,10-dimethyl-4-4-bipyridinium) is a herbicide used to induce several neurotoxic effects similar to PD symptoms in experimental animals (Chanyachukul et al. 2004; Liou et al. 1996). Systemic administration of $\mathrm{PQ}$ into mice induces a dose-dependent decrease in dopaminergic nigral and striatal neurons, which was accompanied by reduction in ambulatory movements. Oxidative stress is the mechanisms by which PQ-induced nigrostriatal dopaminergic neurodegeneration leads to the PD (Singhal et al. 2011). Several studies in rodents have indicated that paraquat causes neurotoxicity via the formation of reactive oxygen species (ROS) and production of apoptosis-related molecules. PQ initiates intracellular formation of ROS through three different pathways that involves formation of the reduced form of PQ by NADPH-cytochrome P450 reductase followed by redox cycle with the involvement of super oxide dismutase (SOD) and glutathione, inhibition of mitochondrial electron transport chain and interaction with another enzymes as NADPH oxidase, nitric oxide synthase, xanthine oxidase and thioredoxin reductase (Gonzalez-Polo et al. 2004).

L-3,4-Dihydroxyphenylalanine (levodopa or L-dopa), the endogenous and metabolic precursor of DA, is given exogenously to patients to raise levels of DA in DA-denervated tissues. It has been used for decades for the symptomatic relief of PD (Cenci 2014; Oertel 2017). Over the years, L-dopa, either administrated alone or coadministrated with inhibitors of peripheral amino acid decarboxylase in order to protect it from its peripheral degradation, remains the gold-standard medication for PD (Goshima et al. 2019). L-Dopa is effective in most PD patients; however, chronic treatment results in motor and behavioral side effects that include dyskinesias or involuntary movements and impulse control disorders (Bastide et al. 2015; Voon et al. 2017). There is controversy over whether the side effects of L-dopa administration could be attributed to the production of free radicals (Ahmadinejad et al. 2017).
Rasagiline $\quad[\mathrm{R}(+)$ - $N$-propargyl-1-aminoindane $] \quad$ is a potent selective irreversible monoamine oxidase $B$ (MAO-B) inhibitor. Rasagiline possesses neuroprotective properties through prolongation of dopamine duration of action in the brain, thus improving the motor symptoms some non-motor symptoms in both early and advanced PD patients (Im et al. 2019; Stocchi et al. 2015).

Phase III clinical studies have declared the significant efficacy of the use of rasagiline for PD treatment, either as an adjunct therapy to L-dopa (Rabey et al. 2000) or alone in early PD conditions (Group 2002). The neuroprotective effect of rasagiline has been markedly confirmed in different in vivo models. In fact, rasagiline increased the survival of dopaminergic neurons in the substantia nigra of 6-hydroxydopamine (6-OHDA)-induced rats (Blandini et al. 2004) and upregulated the tyrosine kinase receptor (Trk)-phosphatidylinositol 3 (PI3) kinase-Akt pathway leading to increased dopaminergic cell survival in the midbrain region of 1-Methyl-4-phenyl-1,2,3,6tetrahydropyridine (MPTP)-induced PD mice (Sagi et al. 2007). Several epidemiological studies have anticipated the association between coffee and caffeine intake and a reduced risk of subsequent development of $\mathrm{PD}$ (Cho et al. 2018; Hong et al. 2020; Moccia et al. 2016). Caffeine is a natural xanthine alkaloid that is widely consumed in coffee, tea, chocolate and soft drinks (Nuhu 2014). It elicits psychostimulatory effect as it can readily cross the blood brain barrier, due to its hydrophobic nature causing alertness and reducing fatigue, leading to more effective functioning in psychomotor tasks demanding fast reactions upon average levels of consumption (Kolahdouzan and Hamadeh 2017; Ullrich et al. 2015). Caffeine is a nonselective $A_{1} / A_{2 A}$ adenosine receptor antagonist (Rascol et al. 2015). The $A_{2 A}$ receptors, specifically located in the basal ganglia (BG) circuit, are of particular interest in PD as they interact functionally and are co-expressed with dopaminergic D2 receptors on the striatal GABAergic neurons of the "indirect" BG pathway directing from the striatum to the globus pallidus (Schiffmann et al. 2007). Preclinical studies showed that the blockade of the $\mathrm{A}_{2 \mathrm{~A}}$ receptor subtype contributes to most neuroprotective effect (Fathalla et al. 2017). Antagonists of the adenosine $\mathrm{A}_{2 \mathrm{~A}}$ (but not $\mathrm{A}_{1}$ ) receptor mimicked the effects of caffeine in acute MPTP and 6-OHDA toxin models of PD (Bove et al. 2005; Pierri et al. 2005). In addition, genetic disruption of the $\mathrm{A}_{2 \mathrm{~A}}$ receptor attenuated acute neurotoxicity in a mouse model of PD. Prospective epidemiologic studies demonstrated the inverse relationship between caffeine intake and PD incidence (Ross et al. 2000). Consumption of caffeine greater than $12 \mathrm{oz} /$ day was linked with reduction in dyskinesia compared with less than $4 \mathrm{oz} /$ day intake (Wills et al. 2013). 
Thus, identification of any promising therapeutic intervention for PD management is of a huge importance. Therefore, the aim of the present study is to investigate the possible synergistic neuroprotective effects of co-administration of caffeine or coffee with L-dopa or rasagiline on PQ-induced neurochemical and behavior impairments in mice.

\section{Methods}

\section{Animals}

Adult old male albino mice, aged 8-9 weeks and weighing 30-35 g, were used in the present study (McCormack and Di Monte 2003). Mice were purchased from the Animal House Colony of the National Research Centre, Dokki, Giza, Egypt. Throughout the period of investigation, the animals were housed in wire mesh plastic cages in groups of five and maintained under suitable laboratory conditions of room temperature $\left(23 \pm 2{ }^{\circ} \mathrm{C}\right)$, relative humidity $(55 \pm 5 \%)$ and 12 -h light $/ 12$-h dark cycle. Animals were provided with standard pellet diet (protein: $23 \%$, fat: $3.25 \%$, carbohydrates and fiber: $~ 68 \%$ ) and allowed free access to tap water. Mice were periodically checked to verify their pathogen free condition All animal procedures were performed according to the Ethics Committee of the National Research Center [ethics approval no. 08020] and in accordance with the recommendations for the proper care and use of laboratory animals "Canadian Council on Animal Care Guidelines, 2011."

\section{Drugs and kits}

Levodopa (L-dopa) and caffeine were a gift from El Nasr Pharmaceutical Company (>98\%). Rasagiline mesylate was purchased from Clearsynth Labs Ltd., Mumbai, India (98\%). Caffeinated coffee (Nescafe) was purchased from market. PQ was purchased from Sigma-Aldrich (St. Louis, MO, USA). Malondialdehyde and superoxide dismutase kits were purchased from Biodiagnostic, Giza, Egypt. Nitric oxide $\left(\mathrm{NO}^{2-} / \mathrm{NO}^{3-}\right)$ assay kit was purchased from Assay Designs, Inc., Ann Arbor, MI, USA. Dopamine and serotonin ELISA kits were purchased from MyBioSource, Inc., San Diego, CA, USA.

\section{Experimental design}

Mice $(n=8)$ were treated with single or combination of drugs: levodopa (L-dopa), rasagiline (R), caffeine (CAF) and coffee (COF)] as assigned in the groups below. Thirty minutes later, a single dose of PQ was injected in mice for the induction of motor behavior and neurochemical disturbances (Chanyachukul et al. 2004; McCormack and Di Monte 2003). The course of treatment was carried out according to Chanyachukul et al. (2004) with modifications. After 90 min from PQ treatment, behavioral tests were carried out followed by scarification of the mice by cervical dislocation. The brains were excised immediately from all animals in different groups and washed with physiological saline. One set was stored at $-80{ }^{\circ} \mathrm{C}$ for estimation of different parameters. Other brain sets were stored in $10 \%$ neutral formalin for histopathological examination.

\section{Animal groups}

Animals were randomly allocated into two main groups: Group 1: animals receiving the vehicle and serve as normal control group and Group 2: mice were injected with PQ (30 mg/kg, i.p.) (Chanyachukul et al. 2004; McCormack and Di Monte 2003). This group was further subdivided into: (1) untreated mice, (2) mice treated with L-dopa [100 mg/kg, i.p.] (McCormack and Di Monte 2003), (3) mice treated with rasagiline (R) $[10 \mathrm{mg} / \mathrm{kg}$, i.p.] (Finberg and Youdim 2002), (4) mice treated with caffeine (CAF) [10 mg/kg, i.p.] (Brothers et al. 2010), (5) mice treated with coffee (at a dose which corresponds to regular human intake of three cups of coffee $\approx 10 \mathrm{mg} /$ kg, i.p. of caffeine) (Costa et al. 2008), (6) mice treated simultaneously with L-dopa and CAF, (7) mice treated simultaneously with L-dopa and COF, (8) mice treated simultaneously with R and CAF and (9) mice treated simultaneously with $\mathrm{R}$ and COF. All treatments were carried out at $30 \mathrm{~min}$ prior to $\mathrm{PQ}$ administration.

\section{Behavioral tests}

All experiments were carried out in similar environmental conditions in the morning between 9 am and $3 \mathrm{pm}$ to diminish circadian effects.

\section{Rotarod test}

The rotarod test has been used to assess motor coordination and balance alterations after PQ injection. Mice were trained to balance on a rotating black grip striated rod (diameter: $3 \mathrm{~cm}$ ) separated in five lanes $57 \mathrm{~mm}$ wide, $20 \mathrm{~cm}$ high from five tilting planks (UGO BASILE, Varese, Italy). Ninety minutes after PQ administration, the treated animals were placed on the rod that rotated at $40 \mathrm{rpm}$ for $60 \mathrm{~s}$ (Rozas et al. 1997). Neurotoxicity was determined by the inability of the animal to remain on the rod.

\section{Forced swim test}

The "behavioral despair" test was performed where mice were individually plunged into a transparent plexiglass cylinder (13 cm diameter X $24 \mathrm{~cm}$ high) containing water $\left(22{ }^{\circ} \mathrm{C} \pm 2{ }^{\circ} \mathrm{C}\right.$ ) to a depth of $40 \mathrm{~cm}$ (UGO Basile S.R.L., Italy. The duration of immobility for the last $4 \mathrm{~min}$ of the 6-min test was measured (Castagne et al. 2010). 


\section{Biochemical tests}

\section{Preparation of mouse brain tissue homogenate}

Tissue homogenates were prepared according to the kit instructions. Brain tissues were rinsed in ice-cold phosphate-buffered saline (PBS) (0.02 mol/L, pH 7.0-7.2) to remove excess blood thoroughly and weighed before homogenization. The brain tissues were homogenized (10 mg tissue to $100 \mu \mathrm{l}$ PBS) with a glass homogenizer (Pyrex ${ }^{\circledR}$ glass pestle tissue grinder, Corning Life Sciences, USA) on ice. The resulting brain homogenates were centrifuged (Z323K, Hermle Labortechnik, Germany) for $15 \mathrm{~min}$ at $5000 \mathrm{rpm}$. The supernatants were stored at $-80{ }^{\circ} \mathrm{C}$ freezer (Nuaire Ultra-Low Freezer, Japan).

\section{Measurement of brain dopamine (DA) level}

Competitive enzyme immunoassay mouse DA ELISA kit was used. This technique utilizes a monoclonal anti-DA antibody and DA-HRP conjugate. The brain homogenate sample and buffer are incubated together with DA-HRP conjugate in pre-coated plate and then incubated with a substrate for HRP enzyme. The product of the enzymesubstrate reaction is measured spectrophotometrically at $450 \mathrm{~nm}$ using a microplate reader (TECAE, A5082, Austria). The intensity of the color is inversely proportional to the DA concentration since DA from brain samples and DA-HRP conjugate compete for the anti-DA antibody binding site. A standard curve is plotted relating the intensity of the color (O.D.) to the concentration of standards. The DA concentration in each sample is interpolated from this standard curve.

\section{Measurement of brain serotonin level}

The mouse brain serotonin content was estimated by adopting the quantitative sandwich ELISA kit. The optical density (O.D.) was measured at $450 \mathrm{~nm}$ using the microplate reader.

\section{Measurement of brain total nitric oxide $\left(\mathrm{NO}^{2-} / \mathrm{NO}^{3-}\right)$}

Total nitric oxide was measure in the brain homogenates of both treated and normal mice using nitric oxide $\left(\mathrm{NO}^{2-} / \mathrm{NO}^{3-}\right)$ assay kit. The measurement of total nitric oxide involves the enzymatic conversion of nitrate to nitrite, by the enzyme nitrate reductase, followed by the colorimetric detection of nitrite as a colored azo dye product of the Griess reaction that absorbs visible light at $540 \mathrm{~nm}$ using the microplate reader. For most accurate determination of total nitric oxide production, both nitrate and nitrite concentrations were quantized in the brain samples.

\section{Measurement of brain superoxide dismutase (SOD) level}

SOD was determined by colorimetric method using commercially available SOD kit. SOD was assayed in terms of its ability to inhibit the radical-mediated chain-propagating autoxidation of epinephrine. The enzyme assay based on adrenochrome absorption at $480 \mathrm{~nm}$ has been improved by measuring the absorption change at $320 \mathrm{~nm}$ using a Cary series UV-Vis spectrophotometer, Agilent Technologies (Sun and Zigman 1978).

\section{Measurement of brain malondialdehyde (MDA) level}

MDA was determined by colorimetric method using commercially available MDA kit (Yagi 1998). MDA reacts with thiobarbituric acid in acidic medium at $95{ }^{\circ} \mathrm{C}$ for $30 \mathrm{~min}$ to form thiobarbituric acid reactive product. The absorbance of the resultant pink product was measured at $534 \mathrm{~nm}$ using the UV-Vis spectrophotometer.

\section{Histopathological examination of brain Hematoxylin and eosin staining}

At the end of the experimental period, a replicate set of animal groups were killed by cervical dislocation and whole brains were dissected immediately. Tissues were fixed in $10 \%$ buffered formalin, processed through ascending grades of alcohol, cleared in xylene and prepared into paraffin blocks. Serial sections 5 microns thick were prepared from each block and stained with hematoxylin and eosin for routine histopathological study (Drury et al. 1976).

\section{Immunohistochemical analysis}

Immunohistochemical (IHC) study was done on additional sections of mice brain tissues to detect glial fibrillary acidic protein (GFAP) for demonstration of astrogliosis. Deparaffinization was performed. Antigen retrieval was done by boiling tissue sections in $10 \mathrm{mM}$ citrate buffer, $\mathrm{pH} 6.0$ for $20 \mathrm{~min}$, followed by cooling at room temperature for $20 \mathrm{~min}$. Primary antibody rabbit polyclonal anti-GFAP antibody (ab7260, Abcam, USA) was applied $5-10 \mu \mathrm{g} / \mathrm{mL}$ for $30 \mathrm{~min}$ at room temperature. UltraVision plus detection system anti-polyvalent, horseradish peroxidase/3, 3'-diaminobenzidine (HRP/ $\mathrm{DAB}$ ) was applied to detect GFAP+ve astrocytes ( $\mathrm{Li}$ et al. 2020). Counterstaining was performed by applying Mayer's hematoxylin for $30 \mathrm{~s}$. Sections of the human brain were run with each batch of IHC stains to act as positive control. Sections omitting the primary antibody and using diluent instead were used as negative control. One negative control and one positive control were used in each run. Positive immunoreactivity was considered when brownish cytoplasmic coloration was seen.

\section{Microscopic examination and photomicrography}

Hematoxylin- and eosin-stained tissue sections were examined using an Olympus CX41 research microscope at the Pathology Department, National Research Centre. Slide 
tissue microphotography was done using a CCD digital camera Olympus DP-12 attached to the Olympus CX41 research microscope. Digital photomicrographic sections were taken at various magnifications.

\section{Morphometric image analysis}

The morphometric image analysis was performed at the Pathology Department, National Research Centre, using the Leica Qwin 500 Image analyzer (LEICA Imaging Systems Ltd, Cambridge, UK), which consisted of a Leica DM-LB microscope with a JVC color video camera attached to a computer system.

The examined slides were placed on the stage of the microscope. The light source was set to the required level. Successful adjustment of illumination was checked for on the monitor. The morphometric image analysis was carried out on hematoxylin- and eosin-stained slides to measure parameters of neuronal cells and pigmented neurons and also carried out on GFAP-immunostained slides. Area measurements of neurons, pigmented neurons and GFAP positively stained cells were taken at magnification $200 \times$. The selected nuclei were surrounded by a line to be covered automatically by a green mask, which is called a binary image. The parameters of this binary image appeared automatically in the form of a table in micrometers, and finally, the mean and standard variation of all parameters examined were determined. The area percentage of the binary image is calculated automatically by the software. The mean percentage of all fields examined is determined.

Optical density measurements of pigmented neurons and GFAP+ve astrocytes were performed with a computerassisted image analysis system. The mean optical density of each region was bilaterally measured on selected brain regions, using consecutive sections in each subject. The degree of reaction was chosen by the color-detect menu. The image was transformed to gray image (a grid of pixels each representing the intensity or the brightness at that point by a range of numbers, from 0 (black) to 255(white) (Kunchok et al. 2019).

\section{Statistical analysis}

Data are presented as mean \pm S.E.M. Differences between groups were statistically analyzed using a one-way analysis of variance followed by a Student-Newman-Keuls post hoc comparison. Data were analyzed using the Sigma Stat software version 11. A result was considered statistically significant where $p<0.05$.

\section{Results}

Behavioral studies

Rotarod test

In the current study, mice were treated with a single injection of PQ preceded by an injection with either saline (positive control), L-dopa, $\mathrm{R}$ or their combination with COF or CAF. PQ administration was associated with significant decrease $(\mathrm{P}<0.001)$ in locomotor activity $(13.80 \pm 1.66 \mathrm{~s})$ which is fourfold lower than that of normal group. All treatments demonstrated threefold to fourfold significant increase $(\mathrm{P}<0.001)$ in locomotor activity compared to the $\mathrm{PQ}$ group. Interestingly, treatment with $\mathrm{L}$-dopa $+\mathrm{CAF}, \mathrm{R}, \mathrm{R}+\mathrm{COF}$ or $\mathrm{R}+\mathrm{CAF}$ normalized the locomotor activity. Moreover, treatment with $\mathrm{R}$ alone demonstrated significant improvement $(P=0.001)$ in motor coordination by $36.36 \%$ when compared to treatment with L-dopa alone. Similarly, $\mathrm{R}+\mathrm{COF}$ combination improved significantly $(\mathrm{P}=0.039)$ the motor coordination by $16.55 \%$ when compared to $\mathrm{L}$-dopa $+\mathrm{COF}$ (Fig. 1A).

\section{Forced swim test}

The PQ-induced mice showed sharp significant $(\mathrm{P}<0.001)$ increase in the immobility time by $165 \%$ compared to normal value. Treatment with L-dopa, or L-dopa with either CAF or COF significantly decreased $(\mathrm{P}<0.001)$ the immobility by 58,93 and $59 \%$, respectively, compared to $\mathrm{PQ}$ group (Figure $1 \mathrm{~B}$ ). In addition, treatment with $R, R+C A F$ or $R+C O F$ significantly decreased $(\mathrm{P}<0.001)$ the immobility by 59,66 and $65 \%$, respectively, compared to $\mathrm{PQ}$ group. Meanwhile, treatments with L-dopa $(63.33 \pm 2.91 \mathrm{~s})$ or L-dopa + COF $(62.83 \pm 1.56 \mathrm{~s})$ as well as $\mathrm{R}(63 \pm 1.73 \mathrm{~s})$ or $\mathrm{R}+\mathrm{CAF}(51.33 \pm 2.40 \mathrm{~s})$ or $\mathrm{R}+\mathrm{COF}(53 \pm 3.22 \mathrm{~s})$ were able to return the immobility time to the normal level. Interestingly, combined treatment with $\mathrm{L}$-dopa + CAF $(10.5 \pm 0.5 \mathrm{~s})$ significantly decreased $(\mathrm{p}=0.001)$ the immobility time by $82 \%$ compared to the normal value (Fig. 1B).

\section{Number of sinking}

In forced swim test, PQ administration exhibited a significant increase $(\mathrm{P}<0.001)$ in the number of sinking $(18.67 \pm 2.96)$ done by mice compared to normal group. Mice treated with L-dopa, L-dopa + CAF or $\mathrm{L}$-dopa $+\mathrm{COF}$ as well as $\mathrm{R}$, or $\mathrm{R}+\mathrm{CAF}$ demonstrated significant reduction $(P<0.001)$ in the number of sink attempts by $96,92,80,93,89$ and $99 \%$, respectively, compared to the PQ group (Fig. 1C).

\section{Biochemical tests}

\section{Brain neurotransmitters}

Dopamine level Dopamine level was significantly decreased in PQ-induced mice brain tissue homogenates $(4.58 \pm 0.26 \mathrm{ng} / \mathrm{g}$ tissue) compared to normal $(31.78 \pm 0.88 \mathrm{ng} / \mathrm{g}$ tissue, $\mathrm{P}<0.001)$. However, treatment with L-dopa, L-dopa + CAF or L-dopa + COF significantly increased $(\mathrm{P}<0.001)$ the brain dopamine level by 2.6-, 5.5and 3.2-fold, respectively, compared to PQ. In addition, 


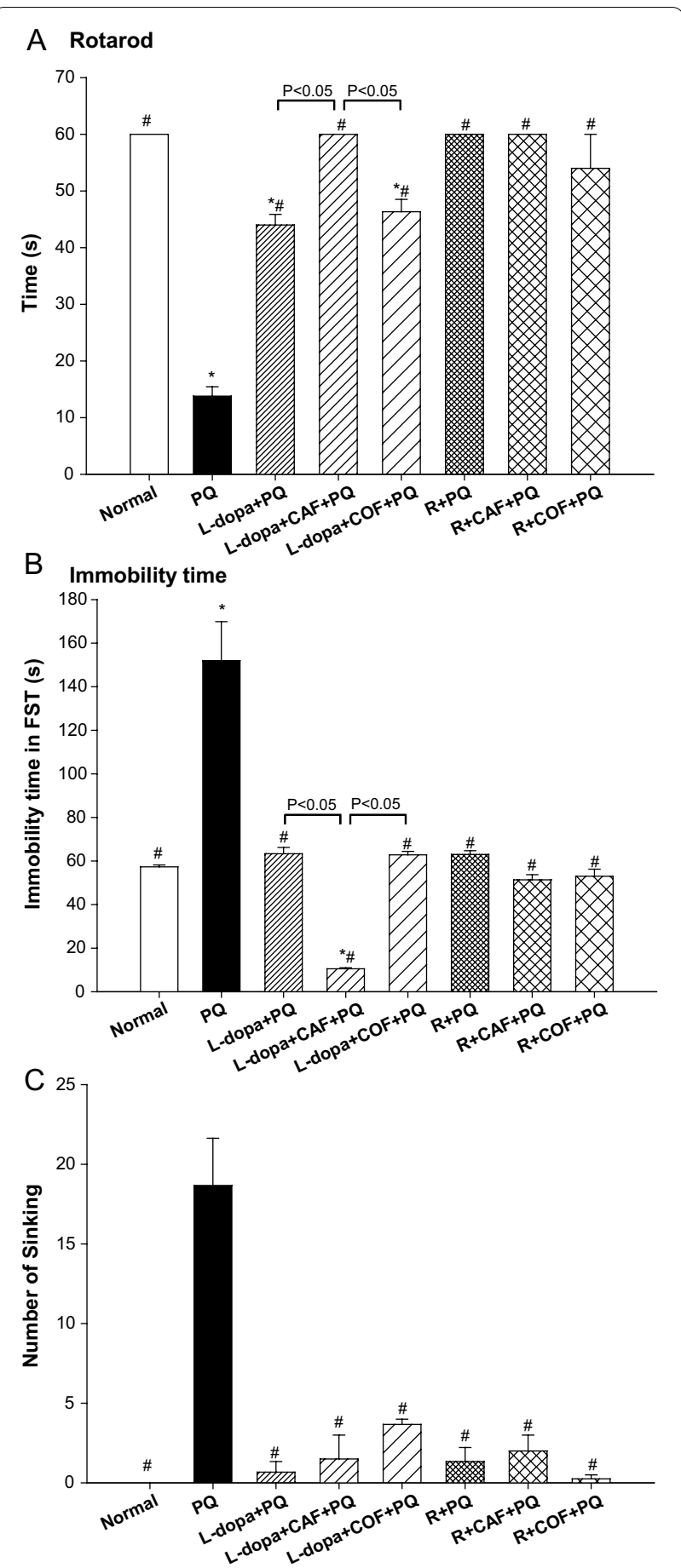

Fig. 1 Effect of each L-dopa and rasagiline (R) alone or in combination with caffeine (CAF) or coffee (COF) on behavioral activity in paraquat (PQ)-treated mice. A Rotarod test, $\mathbf{B}$ Immobility time in forced swim test, $\mathbf{C}$ Number of sinking in forced swim test. Data are presented as mean \pm S.E.M. Differences between groups were statistically analyzed using a one-way analysis of variance followed by a Student-Newman-Keuls post hoc comparison. ${ }^{*}$ Significant from normal group $P<0.05$. "Significant from $P Q$ group $P<0.05$. Lines represent significance $P<0.05$ treatment with $\mathrm{R}, \mathrm{R}+\mathrm{CAF}$, or $\mathrm{R}+\mathrm{COF}$ demonstrated significant increase $(\mathrm{P}<0.001)$ in brain dopamine level by 1.8-, 4.6- and 2.6-fold, respectively, compared to PQ.

Moreover, treatment with CAF demonstrated a pronounced significant effect $(\mathrm{P}<0.001)$ in elevating the brain dopamine level when combined with L-dopa or $\mathrm{R}$ compared to $\mathrm{L}$-dopa and $\mathrm{L}+\mathrm{COF}$ or $\mathrm{R}$ and $\mathrm{R}+\mathrm{COF}$, respectively. Interestingly, treatment with $\mathrm{L}$-dopa, L-dopa + CAF or L-dopa + COF significantly increased the brain dopamine level compared to treatment with $\mathrm{R}$ $(\mathrm{P}<0.001), \mathrm{R}+\mathrm{CAF}(\mathrm{P}<0.001)$, or $\mathrm{R}+\mathrm{COF}(\mathrm{P}=0.002)$, respectively. All the tested treatments failed to significantly $(\mathrm{P}<0.001)$ restore the brain dopamine level to the normal level (Fig. 2A).

Serotonin level Treatment with PQ induced a significant $(\mathrm{P}<0.001)$ decrease in serotonin level $(3.62 \pm 0.18 \mathrm{ng} / \mathrm{g}$ tissue) in mouse brain homogenate compared to the normal group $(29.62 \pm 0.88 \mathrm{ng} / \mathrm{g}$ tissue). Treatment with $\mathrm{L}$-dopa, $\mathrm{L}$-dopa $+\mathrm{CAF}, \mathrm{L}$-dopa $+\mathrm{COF}, \mathrm{R}, \mathrm{R}+\mathrm{CAF}$ or $\mathrm{R}+\mathrm{COF}$ exhibited significant $(\mathrm{P}<0.001)$ increase in brain serotonin content by 2.7-, 6.7-, 3.8-, 1.9-, 5.4- and 3.0-fold, respectively, compared to PQ-treated animals. All the test groups did not restore the serotonin level to normal values. Moreover, treatment with $\mathrm{L}$-dopa $+\mathrm{CAF}$ $(24.17 \pm 0.56 \mathrm{ng} / \mathrm{g}$ tissue $)$ significantly increased $(\mathrm{P}<0.001)$ the brain serotonin level compared to $\mathrm{L}$-dopa $(9.85 \pm 0.35 \mathrm{ng} / \mathrm{g}$ tissue) or L-dopa + COF $(13.78 \pm 0.5 \mathrm{ng} / \mathrm{g}$ tissue). In a similar manner, treatment with $\mathrm{R}+\mathrm{CAF}$ significantly increased $(\mathrm{P}<0.001)$ the brain serotonin level compared to $\mathrm{R}$ or $\mathrm{R}+\mathrm{COF}$. In addition, treatment with $\mathrm{L}$-dopa, $\mathrm{L}$-dopa $+\mathrm{CAF}$ and $\mathrm{L}$-dopa $+\mathrm{COF}$ demonstrated significantly higher serotonin level compared to the corresponding groups treated with $\mathrm{R}$ (Fig. 2B).

\section{Brain antioxidant level}

Nitric oxide brain level Administration of PQ induced a significant increase $(\mathrm{P}<0.001)$ in the nitric oxide $(\mathrm{NO})$ brain level compared to normal and all treated groups (Figure 3A). Treatment with L-dopa $(13.87 \pm 0.46 \mu$ mole $/ g$ tissue), L-dopa + CAF $(6.62 \pm 0.29 \mu$ mole/g tissue) or L-dopa + COF $(10.5 \pm 0.3 \mu$ mole/g tissue) significantly reduced $(\mathrm{P}<0.001)$ the $\mathrm{PQ}(30.4 \pm 1.13 \mu \mathrm{mole} / \mathrm{g}$ tissue $)$ mediated significant increase in NO brain level by 54,78 and $65 \%$, respectively. However, this reduction did not reach the normal nitric oxide brain level. Interestingly, treatment with $\mathrm{L}$-dopa + CAF demonstrated significant reduction $(\mathrm{P}<0.001)$ in brain nitric oxide level than the treatment with either $\mathrm{L}$-dopa or $\mathrm{L}$-dopa $+\mathrm{COF}$. Treatment with $\mathrm{R}, \mathrm{R}+\mathrm{CAF}$ or $\mathrm{R}+\mathrm{COF}$ significantly decreased $(\mathrm{P}<0.001) \mathrm{NO}$ brain level by 28,71 and $58 \%$, respectively, compared to $\mathrm{PQ}$ group. In a similar manner, $\mathrm{R}+\mathrm{CAF}$ 


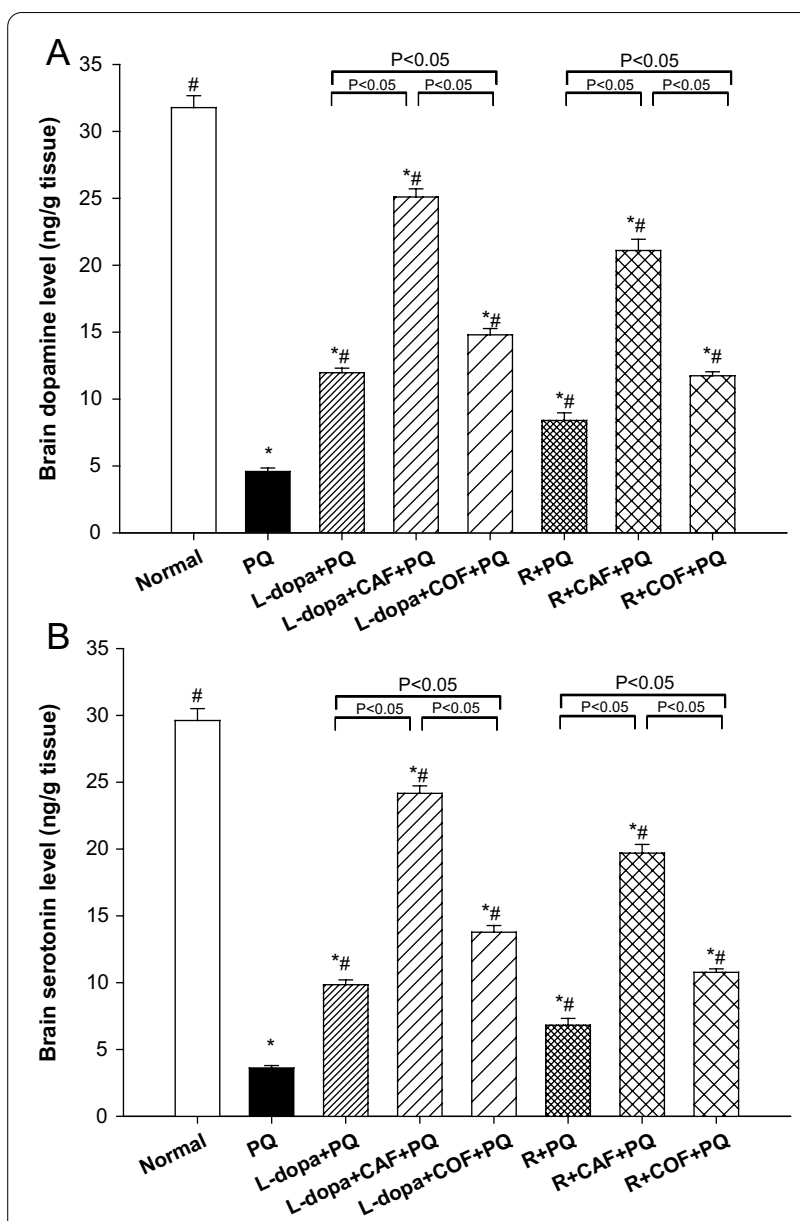

Fig. 2 Effect of each L-dopa and rasagiline (R) alone or in combination with caffeine (CAF) or coffee (COF) on brain neurotransmitters in paraquat $(\mathrm{PQ})$-treated mice. A Brain dopamine level, B Brain serotonin level. Data are presented as mean \pm S.E.M. Differences between groups were statistically analyzed using a one-way analysis of variance followed by a Student-Newman-Keuls post hoc comparison. *Significant from normal group $P<0.05$.

\#Significant from $P Q$ group $P<0.05$. Lines represent significance $P<$ 0.05

$(8.74 \pm 0.25 \mu$ mole/g tissue $)$ significantly decreased $(\mathrm{P}<0.001)$ NO brain level compared to $\mathrm{R}(21.98 \pm 1.05$ $\mu$ mole/g tissue) or $\mathrm{R}+\mathrm{COF}(12.82 \pm 0.4 \mu \mathrm{mole} / \mathrm{g}$ tissue $)$. Moreover, treatment with $\mathrm{L}$-dopa, $\mathrm{L}$-dopa $+\mathrm{CAF}$ and $\mathrm{L}$-dopa + COF demonstrated significant reduction in $\mathrm{NO}$ brain level compared to $\mathrm{R}(\mathrm{P}<0.001), \mathrm{R}+\mathrm{CAF}(\mathrm{P}=0.023)$ or $\mathrm{R}+\mathrm{COF}(\mathrm{P}=0.018)$, respectively (Fig. $3 \mathrm{~A})$.

Superoxide dismutase brain level PQ administration induced a significant decrease by $69 \%$ in mouse SOD brain level compared to the normal group. Treatment with L-dopa, L-dopa + CAF, L-dopa + COF, R, R+CAF or $R+C O F$ exhibited significant increase $(P<0.001)$ in brain SOD content by 2.2-, 2.8-, 2.6-, 2.9-, 3.1- and 3.0fold, respectively, compared to PQ-treated mice. All treatments did not restore the SOD level to the normal level. Moreover, treatment with L-dopa + CAF (761.44 \pm 8.43 $\mathrm{U} / \mathrm{g}$ tissue) significantly increased $(\mathrm{P}<0.001)$ brain SOD level compared to L-dopa $(618.86 \pm 6.61 \mathrm{U} / \mathrm{g}$ tissue $)$ and L-dopa + COF $(716.58 \pm 5.02 \mathrm{U} / \mathrm{g}$ tissue) by 18.7 and $5.9 \%$, respectively. Similarly, treatment with $\mathrm{R}+\mathrm{CAF}$ $(858.34 \pm 8.19 \mathrm{U} / \mathrm{g}$ tissue) significantly increased the brain SOD level by $8.2 \%(\mathrm{P}<0.001)$ and $4.1 \%(\mathrm{P}=0.005)$ compared to $\mathrm{R}(788.15 \pm 4.39 \mathrm{U} / \mathrm{g}$ tissue) and $\mathrm{R}+\mathrm{COF}$ $(823.38 \pm 5.75 \mathrm{U} / \mathrm{g}$ tissue), respectively. In addition, treatment with $\mathrm{R}, \mathrm{R}+\mathrm{CAF}$ or $\mathrm{R}+\mathrm{COF}$ demonstrated significantly elevated $(\mathrm{P}<0.001)$ SOD level compared to the corresponding groups: $\mathrm{L}$-dopa, $\mathrm{L}-\mathrm{dopa}+\mathrm{CAF}$, - -dopa $+\mathrm{COF}$, respectively (Fig. 3B).

Malondialdehyde brain level Mice administered PQ induced a significant $(\mathrm{P}<0.001)$ increase in MDA brain level (10.88 $\pm 1.13 \mathrm{nmole} / \mathrm{g}$ tissue) by $186 \%$ compared to the normal level $(3.8 \pm 0.13 \mathrm{nmole} / \mathrm{g}$ tissue). Treatment with L-dopa, L-dopa + CAF, L-dopa + COF, R, R + CAF or $\mathrm{R}+\mathrm{COF}$, normalized the MDA brain level as they significantly decreased $(\mathrm{P}<0.001)$ its level by $60,67,60$, 67,78 and $74 \%$, respectively, compared to PQ treatment (Fig. 3C).

\section{Histopathological examination \\ Haematoxylin and eosin stained tissue sections}

Sections of normal mice brain showed pyramidal neuronal cells with abundant pigment within cytoplasm together with other non-pigmented neuronal cells with average overall cellularity. Organized cellular Purkinje cell layer with abundant cells was seen within white matter. Cerebellar tissue showed organized cellular granular cell layer in between molecular layer and white matter (Fig. 4A-D).

Administration of PQ caused neurodegenerative changes in the brain tissue, consisting mainly of severe neuronal loss and marked depletion of pigmented neuronal cells as compared to normal (Table 1). The few surviving neuronal cells showed depletion of melanin content within cytoplasm as well as irregularity in size and shape, with irregular contours and deeply basophilic, hyperchromatic nuclei. Several pyknotic nuclei were noticed. Astrogliosis and microgliosis were seen as well. Vacuolar degeneration was seen, being prominent within the background material. Disorganization of Purkinje cell layer was observed (Fig. 5A-D). All treatments showed improvement as compared to PQ; cellularity being restored, neuronal cells increased, pigmented pyramidal neuronal cells increased as well. In addition, 


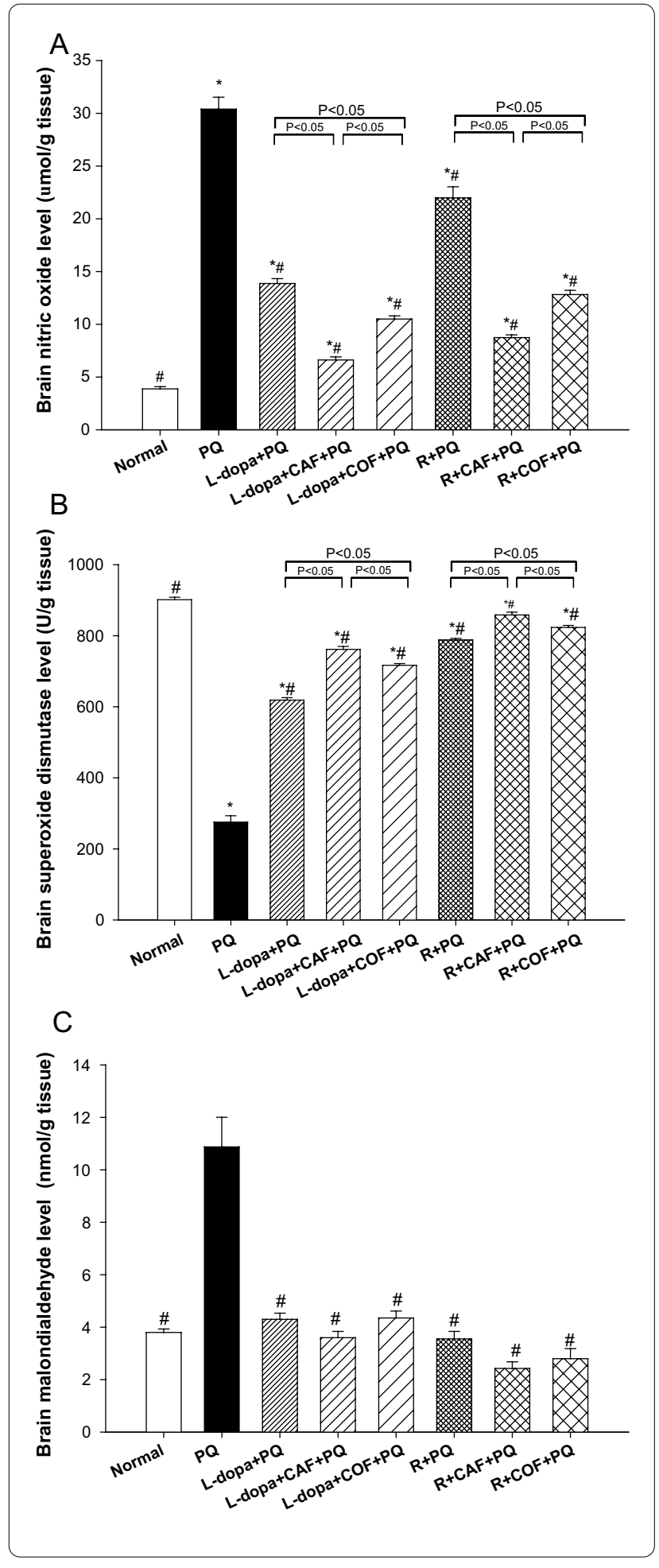

melanin pigment within the neuronal cells also increased. Astrogliosis as well as microgliosis diminished. Vacuolar degeneration within background material also diminished. Purkinje cell layer organization was restored.
Fig. 3 Effect of each L-dopa and rasagiline (R) alone or in combination with caffeine (CAF) or coffee (COF) on antioxidant balance in paraquat (PQ)-treated mice. A Brain nitric oxide level; $\mathbf{B}$ Brain superoxide dismutase level; C Brain malondialdehyde level. Data are presented as mean \pm S.E.M. Differences between groups were statistically analyzed using a one-way analysis of variance followed by a Student-Newman-Keuls post hoc comparison. ${ }^{*}$ Significant from normal group $P<0.05$. "Significant from $P Q$ group $P<0.05$. Lines represent significance $P<0.05$

Neuronal cells became evenly distributed throughout the brain tissue. Pyknosis within nuclei diminished. Irregularity in shape and size of neuronal cells diminished (Figs. 6, 7, 8, 9 and 10; Table 1). The most prominent improvement was in the following descending order: mice administrated $P Q$ and treated with $\mathrm{L}$-dopa $+\mathrm{CAF}$ (Fig. $\quad 7 \mathrm{~A}-\mathrm{D})>\mathrm{L}$-dopa $+\mathrm{COF} \quad$ (Fig. $\quad 8 \mathrm{~A}-\mathrm{D}$ ) $>\mathrm{L}$-dopa (Fig. 6A, B) $>$ R + CAF (Fig. 9A-D) $>$ R + COF (Fig. 10AD) $>$ R (Fig. 6C, D).

\section{Morphometric image analysis on hematoxylin and eosin stained tissue sections}

Results of the morphometric image analysis on hematoxylin- and eosin-stained tissue sections are shown in Table 1. A significant decrease $(\mathrm{P}<0.001)$ in the mean area percentage of neuronal cells and the pigmented neuronal cells in paraquat-treated mice was observed by $76.47 \%$ and $83.87 \%$, respectively, as compared to normal mice. Treatment with $\mathrm{L}$-dopa $+\mathrm{CAF}, \mathrm{L}$-dopa $+\mathrm{COF}$, $\mathrm{L}$-dopa and $\mathrm{R}+\mathrm{CAF}$ in $\mathrm{PQ}$-induced brain neurodegenerative mice showed an increase in the mean area percentage of neuronal cells by $266.67 \%, 75 \%, 116.67 \%$ and $8.33 \%$, respectively, compared to paraquat; this increase is significant $(\mathrm{P}<0.001)$ in the treatment with $\mathrm{L}$-dopa + CAF. In addition, treatment with $\mathrm{L}$-dopa $+\mathrm{CAF}$, L-dopa + COF, L-dopa, R + CAF, R + COF and R demonstrated an increase in the mean area percentage of pigmented neurons by $440 \%, 380 \%, 820 \%, 220 \%, 160 \%$ and $140 \%$, respectively, compared to $\mathrm{PQ}$; this increase is significant in the treatment with $\mathrm{L}-\mathrm{dopa}+\mathrm{CAF}(\mathrm{P}=0.002)$, $\mathrm{L}$-dopa $+\mathrm{COF}(\mathrm{P}=0.008)$ and $\mathrm{L}$-dopa $(\mathrm{P}<0.001)$.

\section{Immunohistochemical analysis}

GFAP (immunohistochemistry and morphometric study) The mean area percentage of GFAP+ve small normal neuronal cells in normal mice brain was $3.44 \pm 0.48 \%$ (Table 2; Fig. 11A). Astrogliosis was demonstrated in brain of $\mathrm{PQ}$-induced neurodegenerative mice group with significant increase $(\mathrm{P}<0.001)$ in $\mathrm{GFAP}+\mathrm{ve}$ large neuronal cells showing numerous branching processes (Table 2; Fig. 11B) reaching 123.26\% compared to normal mice. GFAP+ve astrocytes showed signifi- 


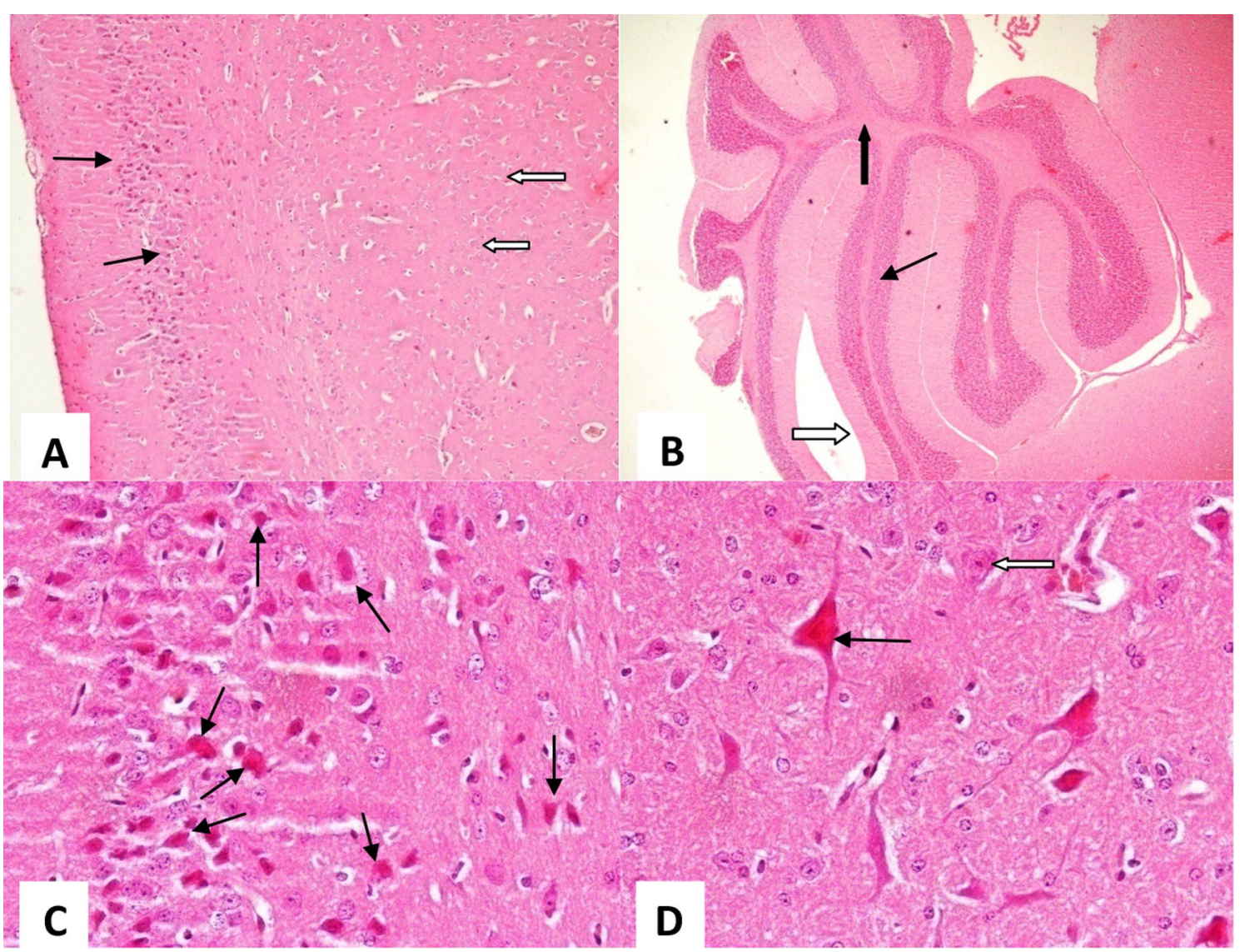

Fig. 4 A Brain tissue of normal mice showing cellular Purkinje cell layer (black arrows) and abundant cells within white matter (white arrows) (H\&E X100). B Cerebellar tissue of normal mice showing granular cell layer (thin black arrow) in between molecular layer (white arrow) and white matter (thick black arrow) (H\&E X100). C Brain tissue of normal mice showing numerous pigmented pyramidal neuronal cells (black arrows) (H\&E X400). D Brain tissue of normal mice showing pyramidal neuronal cells with abundant pigment within cytoplasm (black arrow), together with other non-pigmented neuronal cells (white arrow) (H\&E X400)

Table 1 Effect of each of L-dopa and rasagiline (R) alone or in combination with caffeine (CAF) or coffee (COF) on mean area percentage of neuronal cells and pigmented neurons as well as mean optical density of pigmented neurons in brain tissue sections in paraquat $(\mathrm{PQ})$-treated mice

\begin{tabular}{|c|c|c|c|}
\hline \multirow[t]{2}{*}{ Groups } & \multicolumn{2}{|c|}{ Mean area percentage } & \multirow{2}{*}{$\begin{array}{l}\text { Mean optical density } \\
\text { Pigmented neurons }\end{array}$} \\
\hline & Neuronal cells & Pigmented neurons & \\
\hline Control & $0.51 \pm 0.06$ & $0.31 \pm 0.04$ & $99.41 \pm 4.80$ \\
\hline Paraquat & $0.12 \pm 0.02^{*}$ & $0.05 \pm 0.01^{*}$ & $24.57 \pm 1.21^{*}$ \\
\hline L-Dopa & $0.26 \pm 0.03^{*}$ & $0.46 \pm 0.07^{* \#}$ & $127.83 \pm 0.91^{* \#}$ \\
\hline L-Dopa + CAF & $0.44 \pm 0.10^{\# \$}$ & $0.27 \pm 0.04^{\# \$}$ & $112.21 \pm 5.29^{* \# \$}$ \\
\hline L-Dopa + COF & $0.21 \pm 0.01^{*} €$ & $0.24 \pm 0.02^{\# \$}$ & $116.87 \pm 3.25^{* \#}$ \\
\hline $\mathrm{R}$ & $0.09 \pm 0.03^{*}$ & $0.12 \pm 0.02^{*}$ & $166.05 \pm 7.42^{* \#}$ \\
\hline $\mathrm{R}+\mathrm{CAF}$ & $0.13 \pm 0.02^{*}$ & $0.16 \pm 0.02^{*}$ & $135.83 \pm 3.51^{* \# \& \&}$ \\
\hline $\mathrm{R}+\mathrm{COF}$ & $0.12 \pm 0.02^{*}$ & $0.13 \pm 0.02^{*}$ & $142.35 \pm 3.62^{* \# \&}$ \\
\hline
\end{tabular}

Values are presented as mean \pm S.E.M. *Significant from normal group $\mathrm{P}<0.05$. "Significant from paraquat group $\mathrm{P}<0.05 .{ }^{\$}$ Significant from L-dopa group $\mathrm{P}<0.05$. ${ }^{{ }^{E}}$ Significant from L-dopa + CAF group $\mathrm{P}<0.05 .{ }^{8}$ Significant from $\mathrm{R}$ group $\mathrm{P}<0.05$ 


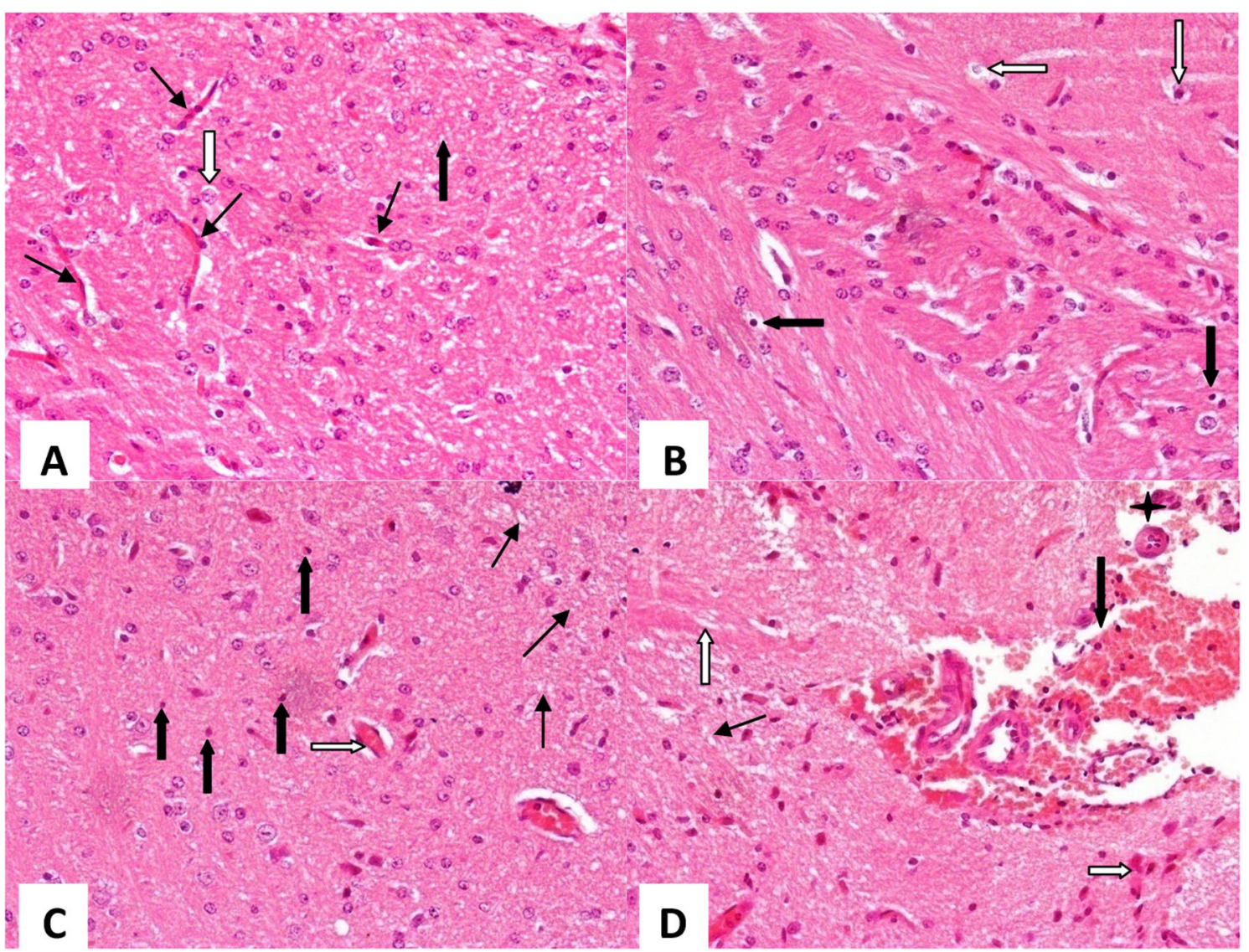

Fig. 5 A Brain tissue of mice treated with PQ showing scattered oligodendroglial cells (white arrow) amidst vacuolated degenerated background (thick black arrow). Scattered blood vessels were seen (thin black arrows) with absence of pigmented neuronal cells. B Brain tissue of mice treated with PQ showing scattered oligodendroglial cells (white arrows) with absence of pigmented neuronal cells. Pyknotic nuclei were seen (thick black arrows). C Brain tissue of mice treated with PQ showing hypocellularity and absence of pigmented neuronal cells. Several pyknotic nuclei were seen (thick black arrows). Vacuolated, degenerated background was noticed (thin black arrows) with ordinary blood vessels (white arrow). D Brain tissue of mice treated with PQ showing degenerated, vacuolated background with congestion (thick black arrow), thick walled blood vessels (star) and attempts at gliosis (white arrow) (H\&E X400)

cant decrease in L-dopa + CAF (Fig. 11C), L-dopa + COF (Fig. 11D), L-dopa (Fig. 11E), R + CAF (Fig. 11F), R + COF (Fig. 11G) and $\mathrm{R}($ Fig. $11 \mathrm{H})$ by $55.86 \%(\mathrm{P}=0.002), 57.68 \%$ $(\mathrm{P}=0.002), \quad 58.72 \% \quad(\mathrm{P}=0.003), \quad 60.81 \% \quad(\mathrm{P}=0.003)$, 69.40\% $(\mathrm{P}<0.001)$ and $73.83 \%(\mathrm{P}<0.001)$, respectively, compared to $\mathrm{PQ}$ group. Treatment with $\mathrm{L}$-dopa $+\mathrm{CAF}$, L-dopa + COF, L-dopa, R + CAF, R + COF and R demonstrated significant reduction in the mean optical density of GFAP+ve astrocytes in brain tissue sections by $25.96 \%$ ( $\mathrm{P}<0.001), 19.87 \%(\mathrm{P}<0.001), 12.97 \%(\mathrm{P}<0.001), 8.42 \%$ $(\mathrm{P}<0.001)$ and $4.23 \%(\mathrm{P}=0.015)$, respectively, compared to PQ (Table 2).

\section{Discussion}

The core therapeutic strategies in the developments PD treatments have mainly focused on: (1) improvement of DA replacement therapies for better management or prevention of the onset of motor complications and (2) discovery of compounds that could modify the course of neurodegeneration. Remarkably, the manipulation of adenosine neurotransmission is considered one of the most valuable therapeutic approaches aimed at addressing these objectives (Simola et al. 2014). Therefore, the current study examined the possible preventive effect of co-administration of caffeine or coffee with L-dopa or rasagiline in paraquat-induced motor behavior alterations and neurochemical disturbances. The present findings demonstrated that combined administration of coffee and caffeine with L-dopa and rasagiline produced 


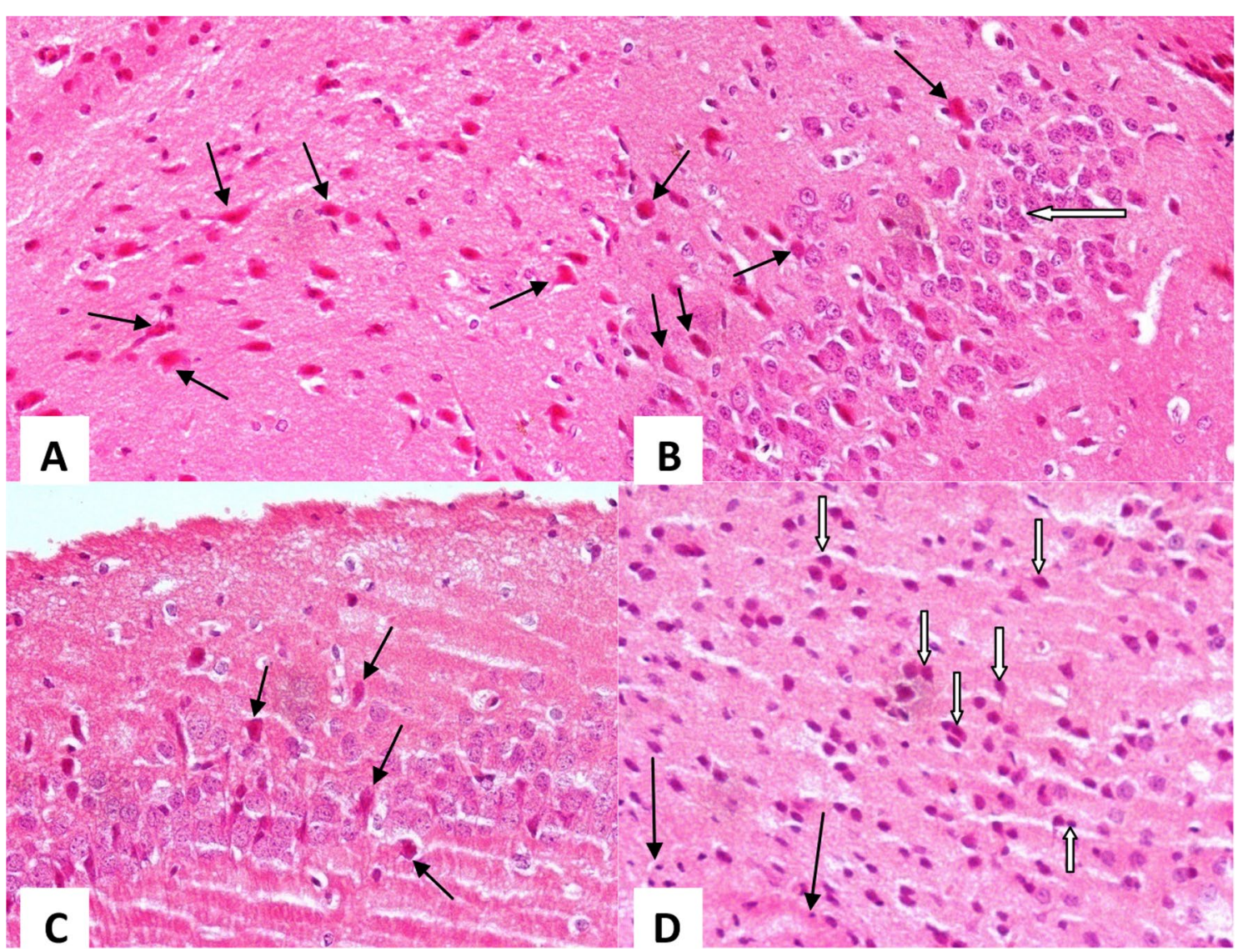

Fig. 6 A Brain tissue of mice treated with (L-dopa $+P Q)$ showing restoration of cellularity with numerous neuronal pyramidal cells showing brownish pigment within cytoplasm (black arrows). B Brain tissue of mice treated with (L-dopa + PQ) showing restored cellular Purkinje cell layer (white arrow) with numerous pigmented neuronal cells (black arrows) (H\&E X 400). C Brain tissue of mice treated with (R+PQ) showing cellular, restored Purkinje cell layer with several prominent pigmented neuronal cells (black arrows). D Brain tissue of mice treated with (R+PQ) showing dense cellularity, scattered cells appeared with irregular contours and deeply basophilic, hyperchromatic nuclei (white arrows). Still, some pyknotic nuclei were seen (thin black arrows) (H\&E X400)

synergistic effects that targeted the brain dopaminergic system resulting in re-balancing of behavior response, neurotransmitters and antioxidant parameters in mouse brain as well as a protective effect from histopathological alterations and astrogliosis, causing their amelioration, as demonstrated by histopathological, GFAP immunohistochemical and image analysis morphometric studies.

In the present work, mice were exposed to PQ which provides a valuable model for understanding the mechanisms of toxicant-induced dopaminergic cell injury and neurodegeneration mainly through increased oxidative stress, synuclein aggregation, mitochondrial dysfunction, $\alpha$-excitotoxicity and autophagy (Colle and Farina 2021; McCormack and Di Monte 2003). Previous studies reported that the peak concentration of $\mathrm{PQ}$ in plasma and brain (Naylor et al. 1995; Widdowson et al. 1996) as well as reduction in the exploratory behavior (motor behavioral activities) of animals was achieved 30 min post-PQ injection (Chanyachukul et al. 2004). Our results demonstrated that PQ significantly resulted in motor impairment, increased immobility time and number of sinking in the forced swim test. In agreement with our results, single subcutaneous systemic injection of PQ $(5,10$ and $20 \mathrm{mg} / \mathrm{kg}$ ) induced significant reductions in locomotive, stereotypic and rotational behavioral activities as compared to control, $30 \mathrm{~min}$ after PQ administration. Moreover, this reduction was reversed on day 3 post-single PQ injection and approached control level over 30-day observation period (Chanyachukul et al. 2004).

Impairment in motor activity is usually accompanied by neurochemical alterations, where a good correlation between the reduction in striatal dopamine levels and rotational behavior was shown $30 \mathrm{~min}$ after PQ injection (Chanyachukul et al. 2004). The mechanism of PQ-induced histopathological changes in mice brain involves: oxidative stress and metabolic processes 


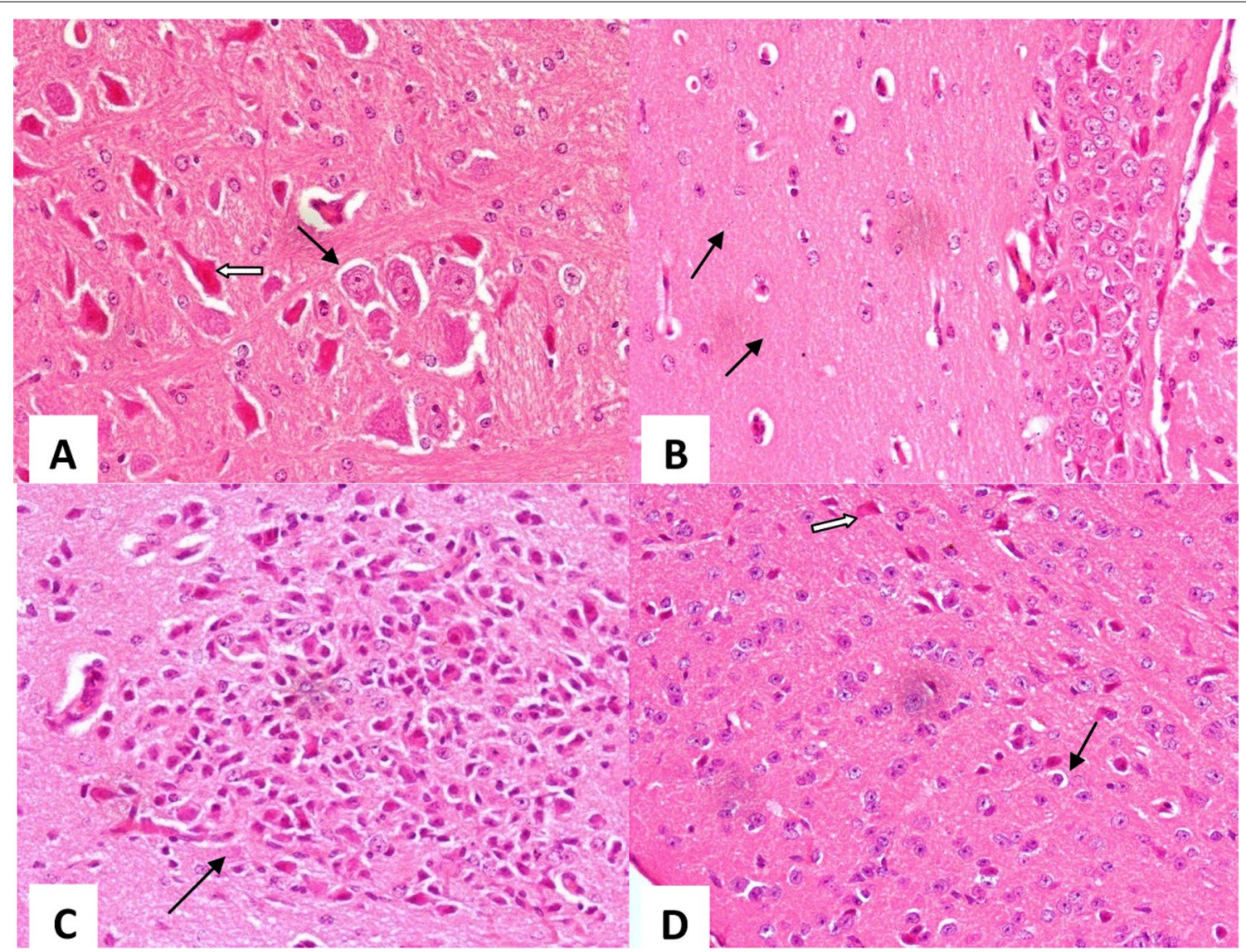

Fig. 7 A Brain tissue of mice treated with ( $L-d o p a+C A F+P Q)$ showing restored cellularity with several neuronal cells, non-pigmented with large rounded nuclei and prominent nucleoli (black arrow). Adjacent pyramidal pigmented neuronal cells were seen as well (white arrow). B Brain tissue of mice treated with (L-dopa $+C A F+P Q)$ showing organized, cellular Purkinje cell layer with adjacent tissues showing marked improvement with no vacuolar degeneration (black arrows). C Brain tissue of mice treated with ( $L$-dopa $+C A F+P Q$ ) showing prominent restored cellularity (black arrow). D Brain tissue of mice treated with (L-dopa $+C A F+P Q)$ showing cellular tissue, with several oligodendroglial (black arrow) and pigmented neuronal cells (white arrow) together with markedly improved background with minimal residual vacuolar degeneration (H\&E X400)

of PQ-inducing excitotoxicity. Also, autophagy, development of $\alpha$-synuclein aggregates, dopamine catabolism variation and tyrosine hydroxylase inactivation are considered as reasons for dopaminergic cells loss (Zhang et al. 2016). In the current study, PQ significantly decreased brain neurotransmitters level: dopamine and serotonin which was confirmed by the histopathological results which revealed histopathological changes including neuronal loss and depletion of pigmented neuronal cells in addition to astrogliosis, as compared to normal, demonstrated by morphometric and immunohistochemical results. These results are in agreement with previous finding that reported that treatment of mice with PQ resulted in loss of dopaminergic neurons in the SNc which is the primary neurodegenerative feature of PD (McCormack et al. 2002). Moreover, a significant decrease in dopamine, dopamine metabolites and norepinephrine content in some brain areas was determined
$30 \mathrm{~min}$ after a single systemic injection of PQ $(20 \mathrm{mg} / \mathrm{kg}$, s.c.). Treatment with PQ $10-20 \mathrm{mg} / \mathrm{kg}$ reduced striatal dopamine content to $74-82 \%$, suggesting that PQ may preferentially target dopaminergic neurons rather than other neurons in the same deeper area (Chanyachukul et al. 2004).

PQ is a potent free radical generator actively accumulated in various tissues as lung and brain (Awadalla 2012). Our results showed that PQ significantly altered the brain antioxidant levels of NO, SOD and DA (oxidative stress biomarkers). The significant increase in brain NO level in PQ-treated mice could lead to the formation of peroxynitrite which is a potent oxidant that can severely damage several biological targets (Ugusman et al. 2019). Over production of NO leads to neurotoxicity by several mechanisms that involve excitotoxicity, DNA damage or post-translational modification of proteins (Zhang et al. 2006). Increased oxidative stress and 


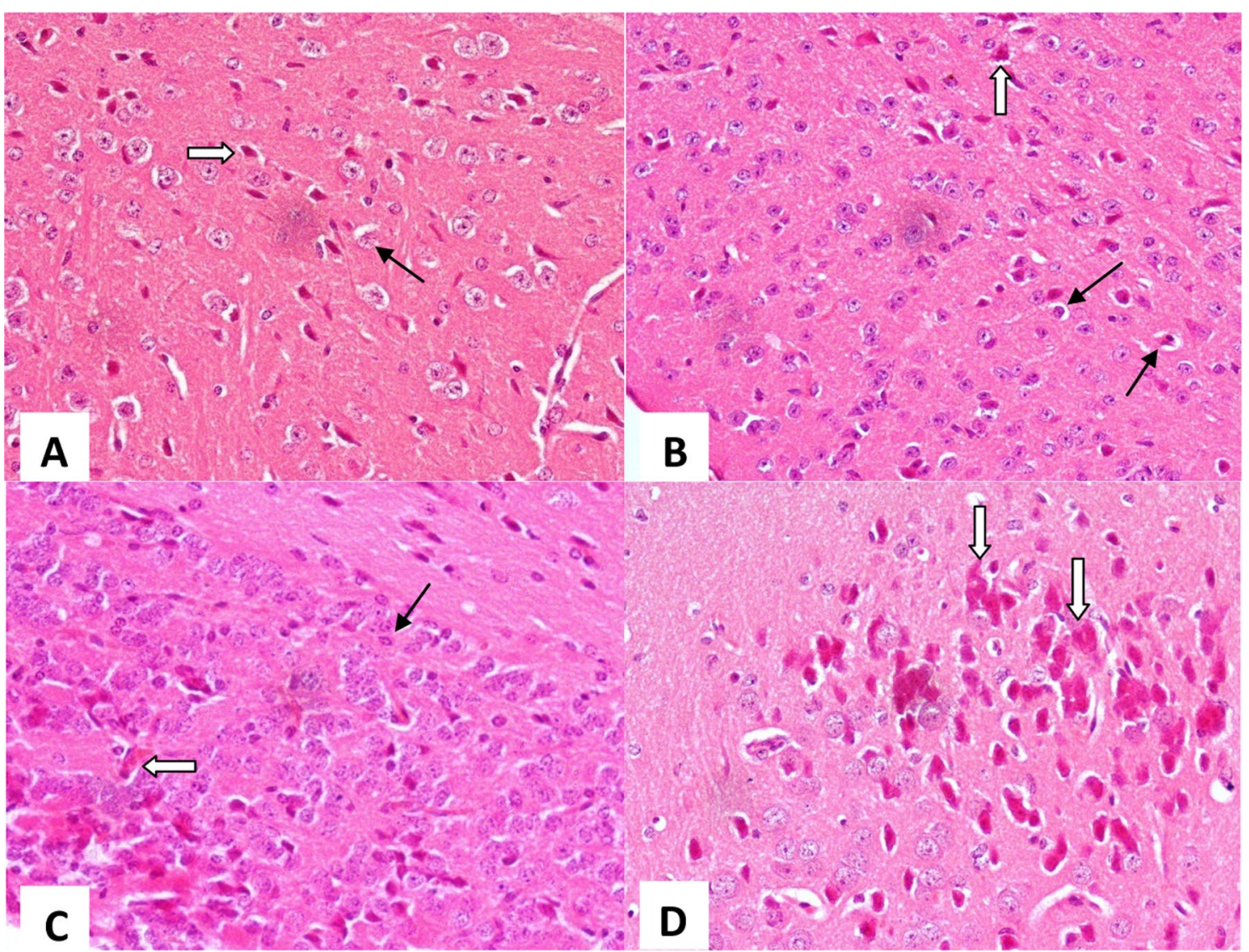

Fig. 8 A Brain tissue of mice treated with ( $L-d o p a+C O F+P Q)$ showing numerous pigmented pyramidal neuronal cells (white arrow) among several other oligodendroglial cells (black arrow). B Brain tissue of mice treated with $(L+C O F+P Q)$ showing restored prominent cellularity with numerous oligodendroglial cells (black arrows) with scattered pigmented pyramidal neuronal cells (white arrow). C Brain tissue of mice treated with (L-dopa + COF + PQ) showing cellular, organized Purkinje cell layer (black arrow) with scattered pigmented neuronal cells (white arrow). D Brain tissue of mice treated with ( $L$-dopa $+C O F+P Q)$ showing restored marked pigmentation within numerous neuronal pyramidal pigmented cells (white arrows) (H\&E X400)

nitric oxide synthase (NOS)-mediated nitric oxide production were found to play a role in microglial activation. Several signaling pathways such as tyrosine kinase pathway, p38 mitogen-activated protein kinase (MAPK) and nuclear factor kappa B (NF-kB) were reported to be involved in iNOS-mediated nitrite oxide production and neuronal injury (Gupta et al. 2010).

In addition, our study demonstrated that PQ significantly reduced the brain antioxidant level of SOD which is reported to play an important role in the protection against oxidative toxicity as it catalyzes the dismutations of superoxide anion free radicals to less toxic forms that involves hydrogen peroxide and molecular oxygen (Ighodaro and Akinloye 2018). During PQ exposure, large amounts of superoxide ion are generated due to redox cycling of the herbicide. NO reacts faster with superoxide ion $\mathrm{O}_{2}^{*-}$ than any other known biological molecule and is produced in high enough concentrations to outcompete endogenous levels of SOD. Once $\mathrm{ONOO}^{-}$is formed, it can chemically change nucleic acids, amino acids and thiol-containing proteins and peptides (Moran et al. 2010). In agreement with our results, ZeinvandLosertani et al. (2018) reported that acute administration of PQ significantly decreased SOD activity, which led to the depletion of antioxidant stores in liver tissue and consequently oxidative damage, in addition to decrease in total thiol groups content in liver homogenate and increased hepatic lipid peroxidation (ZeinvandLorestani et al. 2018). Moreover, SOD protected against the development of acute PQ toxicity when injected 60 min post-PQ administration (Wasserman and Block 1978). Knowing that PQ belongs to a broad class of redox cycling compounds known to produce ROS, mitochondria are strongly implicated as a major source of paraquat-induced ROS generation in rat brain (Castello 


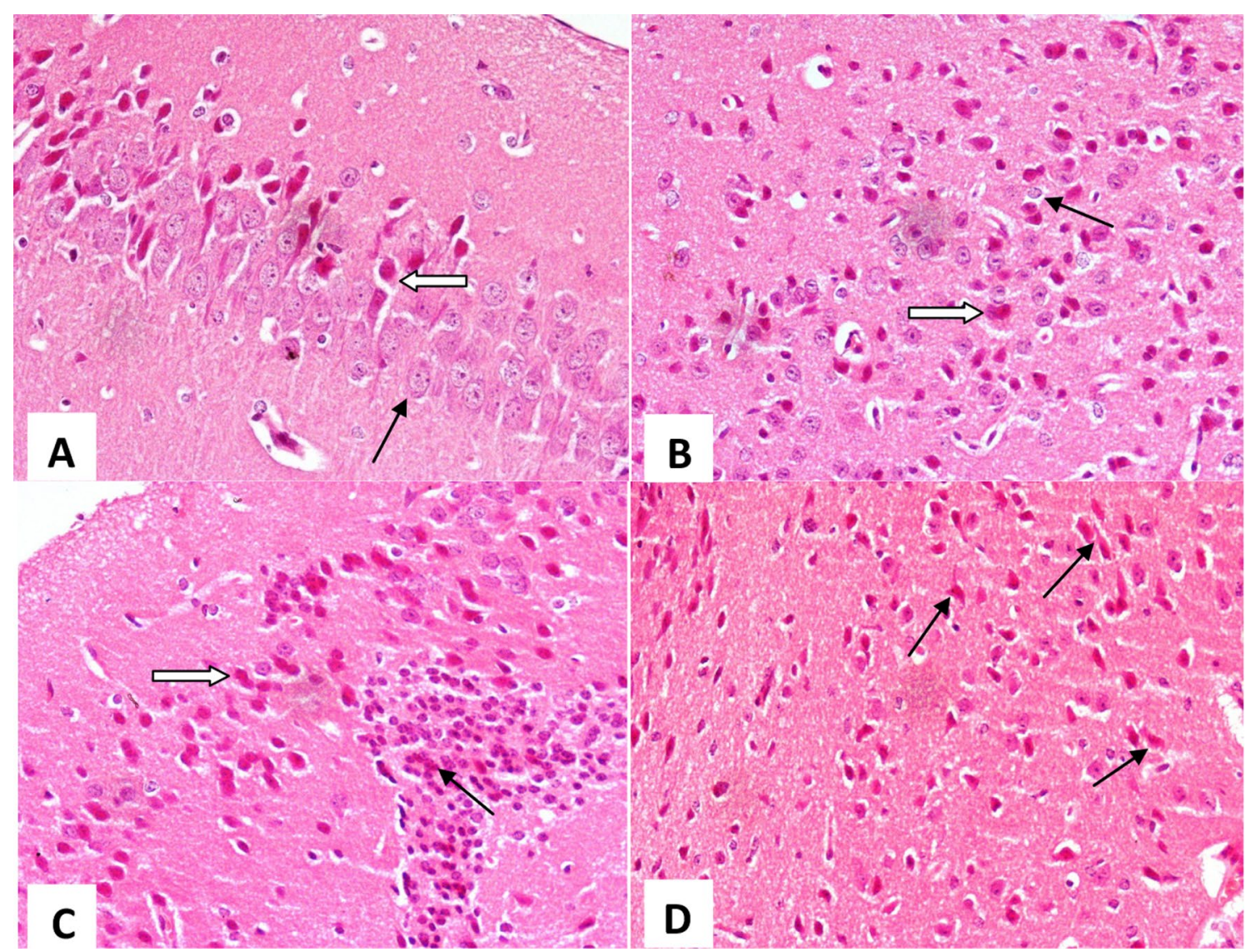

Fig. 9 A Brain tissue of mice treated with $(R+C A F+P Q)$ showing preserved, organized Purkinje cell layer (black arrow) with numerous pigmented pyramidal neuronal cells (white arrow). B Brain tissue of mice treated with $(R+C A F+P Q)$ showing restored marked cellularity with numerous pigmented neuronal cells (white arrow) intermixed with several oligodendroglial cells (black arrow). C Cerebellar tissue of mice treated with $(\mathrm{R}+\mathrm{CAF}+\mathrm{PQ}$ ) showing organized, cellular, granular cell layer (black arrow) with adjacent numerous pigmented pyramidal neuronal cells (white arrow). D Brain tissue of mice treated with $(R+C A F+P Q)$ showing prominent restored cellularity and marked pigmentation (black arrows) (H\&E X400)

et al. 2007). Superoxides generated by mitochondrial dysfunction can amplify NLRP3 inflammasome signaling pathways, which augments the dopaminergic neurodegenerative process (Ikawa et al. 2020; Sarkar et al. 2017). In addition, induction of oxidative stress affects the astrocyte in terms of morphologic and phenotypic changes that can lead to astrogliosis mostly identified by increased production of GFAP (Li and Stary 2016).

Restoration of neurochemical parameters was noticed and documented histologically when using treatment with each of L-dopa, R, CAF and COF in the brain of mice exhibiting PQ histopathological changes. The present study showed that treatment with L-dopa significantly improved the behavioral response, brain DA and ST, the brain antioxidant parameters and improved the histopathological features in PQ-induced neurochemical disturbances and motor behavior impairment in mice. This could be attributed to the capability of L-dopa in preventing PQ neurotoxicity possibly by acting as competitive uptake inhibitors and thus limiting its access into the CNS (Shimizu et al. 2001). Pretreatment with L-dopa, which is transported across the blood brain barrier through the same neutral amino acid carrier (system $\mathrm{L}$ carrier) as $\mathrm{PQ}$, demonstrated a neuroprotective effect when administered $30 \mathrm{~min}$ prior to $\mathrm{PQ}$ via reducing the ROS, hydroxyl radical $\mathrm{HO}$ content in the striatal tissue and reduced the accumulation of PQ in midbrain sections of mice as indicated by the lack of paraquat immunoreactivity in this part of the brain thus modifying the effects of toxicants targeting the nigrostriatal system (Ghosh et al. 2018; McCormack and Di Monte 2003; Rai and Singh 2020). On the other hand, in vitro studies of L-dopa using physiologically relevant concentrations showed certain antioxidant properties combined with potentially cytotoxic pro-oxidant characteristics. Also, L-dopa can undergo auto-oxidation, producing 


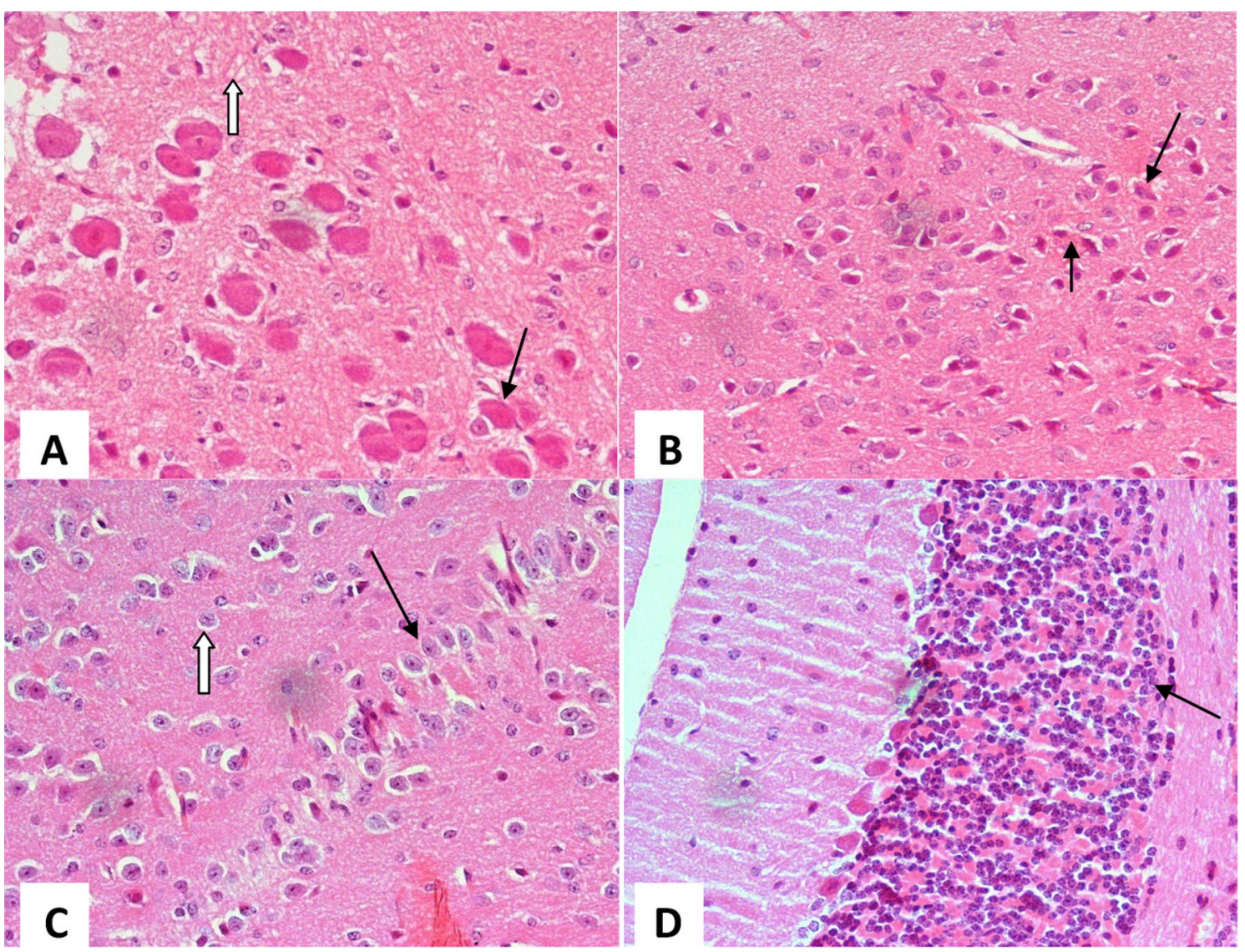

Fig. 10 A Brain tissue of mice treated with $(R+C O F+P Q)$ showing prominent cellularity with numerous pyramidal pigmented neuronal cells (black arrow); however, still, residual vacuolar degeneration was observed in the background (white arrow). B Brain tissue of mice treated with $(\mathrm{R}+\mathrm{COF}+\mathrm{PQ})$ showing restored cellularity; however, pigmented pyramidal neuronal cells still showed some changes with irregular contour (black arrows). C Brain tissue of mice treated with $(R+C O F+P Q)$ showing organized, yet hypocellular Purkinje cell layer (black arrow) with adjacent numerous oligodendroglial cells (white arrow). D Brain cerebellar tissue of mice treated with $(R+C O F+P Q)$ showing preserved, organized, cellular, granular layer (black arrow) (H\&E X400)

Table 2 Effect of each of L-dopa and rasagiline (R) alone or in combination with caffeine (CAF) or coffee (COF) on mean area percentage and mean optical density of GFAP+ve astrocytes in brain tissue sections in paraquat (PQ)-treated mice

\begin{tabular}{lll}
\hline Groups & Mean area percentage & Mean optical density \\
\hline Control & $3.44 \pm 0.48$ & $69.94 \pm 1.26$ \\
Paraquat & $7.68 \pm 1.52^{*}$ & $96.07 \pm 0.26^{*}$ \\
L-dopa & $3.17 \pm 0.23^{\#}$ & $83.61 \pm 0.81^{* \#}$ \\
L-dopa + CAF & $3.39 \pm 0.34^{\#}$ & $71.13 \pm 1.67^{\# \$}$ \\
L-dopa + COF & $3.25 \pm 0.91^{\#}$ & $76.98 \pm 1.30^{* \# \xi}$ \\
$R$ & $2.01 \pm 0.59^{\#}$ & $95.28 \pm 0.51^{*}$ \\
R+CAF & $3.01 \pm 0.31^{\#}$ & $87.98 \pm 0.58^{* \# \&}$ \\
R+COF & $2.35 \pm 1.00^{\#}$ & $92.01 \pm 0.43^{* \# \& \pi}$
\end{tabular}

Values are presented as mean \pm S.E.M. *Significant from normal group $P<0.05$. "Significant from paraquat group $\mathrm{P}<0.05$. ${ }^{\$}$ Significant from L-dopa group $\mathrm{P}<0.05$. ${ }^{{ }}$Significant from L-dopa + CAF group $\mathrm{P}<0.05 .{ }^{\&}$ Significant from $\mathrm{R}$ group $\mathrm{P}<0.05$. ${ }^{\text {SSignificant }}$ from $\mathrm{R}+\mathrm{CAF}$ group $\mathrm{P}<0.05$ the neurotoxin, 6-hydroxydopamine (6-OHDA), dopamine oxidation product, and toxic quinones and several ROS, such as hydroxyl radicals (Borah and Mohanakumar 2010). Our histopathological results revealed the improvement caused by treatment with L-dopa in the form of restoration of cellularity with numerous neuronal pyramidal cells showing brownish pigment within cytoplasm as well as restored cellular Purkinje cell layer. Shin el al., 2009 agreed with our results declaring that L-dopa showed a neuroprotective effect elaborated immunohistochemically in MPTP-treated mice by the marked elevation in the number of tyrosine hydroxylase immunoreactive and Nissl-stained cells (Shin et al. 2009). In addition, treatment with L-dopa in rotenone-induced striatal histopathological alterations showed that some neurons regain their normal size (Badawi et al. 2020).

In the present study, treatment with rasagiline normalized the locomotor activity and immobility time and 


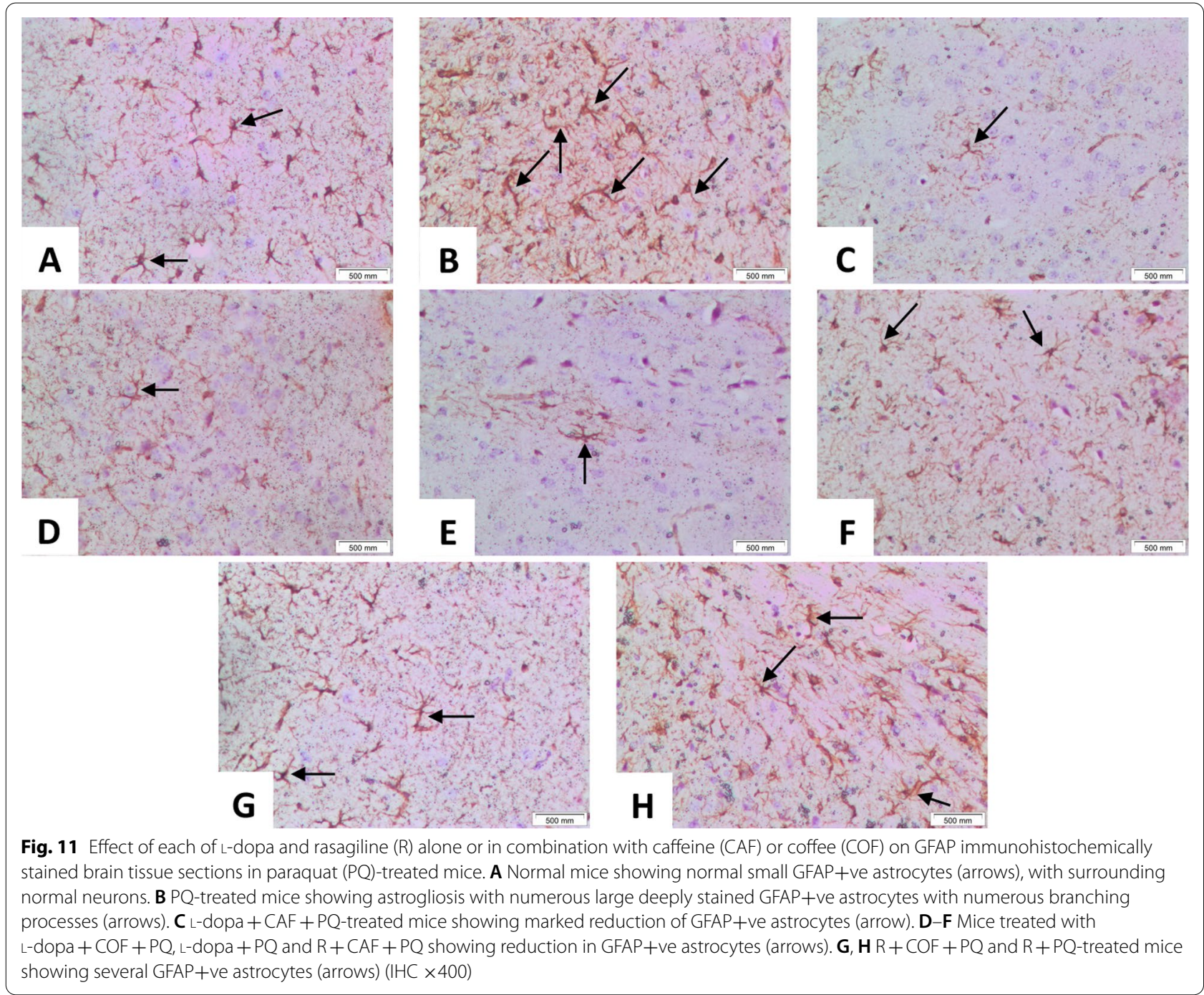

significantly lowered number of sink attempts compared to $P Q$. In addition, rasagiline significantly increased brain DA, ST and SOD, but decreased NO and MDA levels compared to $\mathrm{PQ}$. In agreement with the present results, rasagiline prevented neurodegradation in the brain striatum in mice (Baranyi et al. 2016). This was also documented by the histopathological results of brain tissue of mice receiving $\mathrm{PQ}$ and treated with rasagiline which showed cellular restored Purkinje cell layer with several prominent pigmented neuronal cells and dense cellularity, which was also confirmed by morphometric study. In agreement with our results, treatment with rasagiline in rotenone-induced histopathological alteration mouse model showed improvement in the form of moderate increase in neuronal size and number (Badawi et al. 2020).

The neuroprotective mechanism of rasagiline against apoptosis involves reduction in caspase-3 activation, activation of protein kinase $\mathrm{c}(\mathrm{PKC}) \alpha$ and $\varepsilon$, regulation of the Bcl-2 family proteins and mitochondrial membrane stabilization (Chau et al. 2010). Rasagiline raised the survival of dopaminergic neurons in the substantia nigra and abolished the motor stereotypes behaviors associated with nigrostriatal lesion induced by 6-OHDA (Blandini et al. 2004). Rasagiline inhibited $N$-methyl(R)salsolinol (endogenous dopaminergic neurotoxin), 6-OHDA and peroxynitrite toxin-induced mitochondrial impairmentrelated apoptosis in human neuroblastoma SH-SY5Y cells (Maruyama et al. 2000). It increased dopaminergic cell survival in the midbrain by up-regulation of the tyrosine kinase receptor (Trk)-phosphatidylinositol 3 (PI3) kinase-Akt pathway when administered chronically to post-MPTP-lesioned mice (Sagi et al. 2007). In addition, treatment with rasagiline was reported to increase ST level and decrease its turnover (Weinreb et al. 2015). 
Rasagiline treatment induced the antioxidant enzymes SOD and catalase in substantia nigra and striatum (Carrillo et al. 2000) and attenuated microglia activation related oxidative stress in vitro (Trudler et al. 2014). In nigral toxicity model induced by paraquat in neuroblastoma cell line, and cells over-expressing wild-type and A53T mutation of alpha-synuclein, rasagiline increased cellular glutathione levels and reduced superoxide generation, suggesting that its protective actions incorporate an antioxidant effect (Chau et al. 2010).

In the current study, the combined treatment of COF or CAF with L-dopa or rasagiline was targeted to investigate the best potential approach in the management PQinduced neurochemical disturbances and motor behavior impairments. In behavioral tests, rasagiline combination with COF increased the locomotor activity in rotarod test compared to L-dopa + COF. In addition, L-dopa combinations decreased the immobility time in the forced swim test compared to rasagiline combinations, while simultaneous co-administration of L-dopa and caffeine provided similar increase in locomotor activity compared to coadministration of rasagiline and CAF. The administration of rasagiline together with COF or CAF possessed some beneficial effects where it significantly increased the DA and SOD but decreased MDA brain level compared to the respective combination with L-dopa. On the other hand, L-dopa combination with coffee or caffeine significantly increased serotonin and decreased the NO brain levels compared to the respective rasagiline combination.

The neuroprotective effects of caffeine were demonstrated in several in vivo experimental PD models through a variety of mechanisms such as antagonism of $\mathrm{A}_{2 \mathrm{~A}}$ receptor and activation of the PI3K/Akt pathways signaling pathway (Ikram et al. 2020; Nakaso et al. 2008). Blocking of $\mathrm{A}_{2 \mathrm{~A}}$ receptor by caffeine leads to downregulation of the presynaptic release of excitatory neurotransmitter glutamate through lowering $\mathrm{Ca}^{2+}$ influx, thus avoiding excessive calcium releasing-related neurotoxicity (Hong et al. 2020). In addition, inhibition of microglia activation through blocking of A2A receptor by caffeine leads to inhibition of the release of inflammatory cytokines and hence protection from neuroinflammation as well as regulating reactive oxygen species and other factors responsible for neuronal loss (Ikram et al. 2019; Liu et al. 2016).

Consumption of coffee has been associated with reduced risk of developing $\mathrm{PD}$ (Xu et al. 2005). In a large prospective study, the role of caffeine in caffeinated coffee was found to be linked with lower PD risk, but not in decaffeinated coffee (Ascherio et al. 2001). An inverse relationship between caffeine and PD risk is possibly due to the direct neuroprotective effect of caffeine. Caffeine could significantly restore the levels of DA and its metabolites in the striatum (Xu et al. 2010) and counteracted the neuroinflammation induced by acute exposure to the dopaminergic neuron toxin MPTP at a dose in mice corresponding to human consumption of a single cup of coffee (Carta et al. 2009).

In a similar manner, caffeine reduced nigrostriatal neuron injury triggered by direct intracerebral infusion of 6-OHDA in rats that was accompanied with restoration of the levels of DA and its metabolites in the striatum (Aguiar et al. 2006). Moreover, in chronic paraquat as well as "dual pesticide" model of PD in mice (PQ and maneb), caffeine attenuated the degradation of DA neurons through significantly reducing the tyrosine hydroxylase immunoreactivity neuron loss (Kachroo et al. 2010). In addition, treatment with caffeine in rotenone PD rat model improved the histopathological alterations in the neurons of the substantia nigra parts compacta (Soliman et al. 2016). Such pharmacological findings came in agreement with the histopathological and GFAP results of the current study, where combined treatment with coffee or caffeine demonstrated prominent improvement in neurodeteriorations caused by PQ compared to treatment with L-dopa or rasagiline alone (Khan et al. 2019; Machado et al. 2020).

\section{Conclusions}

The approach of co-administration of coffee or caffeine as A2A receptor antagonists with L-dopa or rasagiline can synergistically affect the histopathological and biochemical changes as well as neurotransmitters in paraquatinduced mice. Therefore, it possesses a new therapeutic strategy for PD management through using caffeine in its pure form or as a diet component. Future studies are needed on the inclusion of caffeine or coffee in diet strategies of patients undergoing PD medications, as well as normal population for future prevention of neurodegenerative diseases.

\section{Abbreviations \\ PD: Parkinson's disease; PQ: Paraquat; L-Dopa: Levodopa; R: Rasagiline; CAF: Caffeine; COF: Coffee; DA: Dopamine; NO: Nitric oxide; SOD: Super oxide dismutase; MDA: Malondialdehyde; SN: Substantia nigra; ROS: Reactive oxygen species; 6-OHDA: 6-Hydroxydopamine; Trk: Tyrosine kinase receptor; MPTP: 1-Methyl-4-phenyl-1,2,3,6-tetrahydropyridine; BG: Basal ganglia; GFAP: Glial fibrillary acidic protein.}

\section{Acknowledgements}

The authors are grateful to the National Research Centre for supporting this work.

\section{Authors' contributions}

MA contributed to the design of the experiments, performed the pharmacology part and interpreted the data of the pharmacology section. MA wrote and revised the paper. YM designed the experiments, interpreted the data of the pharmacology section and revised the paper. AS contributed to the design of the experiments and performed the pharmacology part. AG designed and 
performed the histopathological experiments, interpreted the data and wrote and revised the histopathology section. All authors read and approved the final manuscript.

\section{Funding}

This study was supported by the National Research Centre (NRC), Giza, Egypt, Project No. 10010302.

\section{Availability of data and materials}

All data generated or analyzed during this study are included in this published article.

\section{Declarations}

\section{Ethics approval and consent to participate}

All animal procedures were performed according to the Ethics Committee of the National Research Center [ethics approval no. 08020] and in accordance with the recommendations for the proper care and use of laboratory animals "Canadian Council on Animal Care Guidelines, 2011."

\section{Consent for publication}

Not applicable.

\section{Competing interests}

The authors declare that they have no competing interests.

\section{Author details}

${ }^{1}$ Medicinal and Pharmaceutical Chemistry Department (Pharmacology Group), Pharmaceutical and Drug Industries Research Institute, National Research Centre (ID: 60014618), 33 El Bohouth St., P.O. 12622, Dokki, Giza, Egypt. ${ }^{2}$ Pathology Department, Medical Research and Clinical Studies Institute, National Research Centre (ID: 60014618), 33 El Bohouth St., P.O. 12622, Dokki, Giza, Egypt.

Received: 21 August 2021 Accepted: 27 November 2021

Published online: 14 December 2021

\section{References}

Aguiar LM et al (2006) Neuroprotective effects of caffeine in the model of 6-hydroxydopamine lesion in rats. Pharmacol Biochem Behav 84:415419. https://doi.org/10.1016/j.pbb.2006.05.027

Ahmadinejad F, Geir Moller S, Hashemzadeh-Chaleshtori M, Bidkhori G, Jami MS (2017) Molecular mechanisms behind free radical scavengers function against oxidative stress. Antioxidants. https://doi.org/10.3390/antio $\times 6030051$

Ascherio A, Zhang SM, Hernan MA, Kawachi I, Colditz GA, Speizer FE, Willett WC (2001) Prospective study of caffeine consumption and risk of Parkinson's disease in men and women. Ann Neurol 50:56-63. https://doi.org/ 10.1002/ana.1052

Awadalla EA (2012) Efficacy of vitamin C against liver and kidney damage induced by paraquat toxicity. Exp Toxicol Pathol 64:431-434. https://doi. org/10.1016/j.etp.2010.10.009

Badawi HM, Abdelsalam RM, Abdel-Salam OM, Youness ER, Shaffie NM, Eldenshary EDS (2020) Bee venom attenuates neurodegeneration and motor impairment and modulates the response to L-dopa or rasagiline in a mice model of Parkinson's disease. Iran J Basic Med Sci 23:1628-1638. https:// doi.org/10.22038/ijbms.2020.46469.10731

Baranyi M et al (2016) Novel (Hetero)arylalkenyl propargylamine compounds are protective in toxin-induced models of Parkinson's disease. Mol Neurodegener 11:6. https://doi.org/10.1186/s13024-015-0067-y

Bastide MF et al (2015) Pathophysiology of L-dopa-induced motor and nonmotor complications in Parkinson's disease. Prog Neurobiol 132:96-168. https://doi.org/10.1016/j.pneurobio.2015.07.002

Blandini F, Armentero MT, Fancellu R, Blaugrund E, Nappi G (2004) Neuroprotective effect of rasagiline in a rodent model of Parkinson's disease. Exp Neurol 187:455-459. https://doi.org/10.1016/j.expneurol.2004.03.005
Borah A, Mohanakumar KP (2010) L-Dopa-induced 6-hydroxydopamine production in the striata of rodents is sensitive to the degree of denervation. Neurochem Int 56:357-362. https://doi.org/10.1016/j.neuint.2009.11.008

Bove J, Serrats J, Mengod G, Cortes R, Tolosa E, Marin C (2005) Neuroprotection induced by the adenosine A2A antagonist CSC in the 6-OHDA rat model of parkinsonism: effect on the activity of striatal output pathways. Exp Brain Res 165:362-374. https://doi.org/10.1007/s00221-005-2302-1

Brothers HM, Marchalant Y, Wenk GL (2010) Caffeine attenuates lipopolysaccharide-induced neuroinflammation. Neurosci Lett 480:97-100. https:// doi.org/10.1016/j.neulet.2010.06.013

Carrillo M et al (2000) Enhancing effect of rasagiline on superoxide dismutase and catalase activities in the dopaminergic system in the rat. Life Sci 67:577-585. https://doi.org/10.1016/s0024-3205(00)00643-3

Carta AR, Kachroo A, Schintu N, Xu K, Schwarzschild MA, Wardas J, Morelli $M(2009)$ Inactivation of neuronal forebrain A receptors protects dopaminergic neurons in a mouse model of Parkinson's disease. J Neurochem 111:1478-1489. https://doi.org/10.1111/j.1471-4159.2009. 06425.x

Castagne V, Moser P, Roux S, Porsolt RD (2010) Rodent models of depression: forced swim and tail suspension behavioral despair tests in rats and mice. Current protocols in pharmacology Chapter 5:Unit 58. https://doi.org/10.1002/0471141755.ph0508s49

Castello PR, Drechsel DA, Patel M (2007) Mitochondria are a major source of paraquat-induced reactive oxygen species production in the brain. J Biol Chem 282:14186-14193. https://doi.org/10.1074/jbc.M700827200

Cenci MA (2014) Presynaptic mechanisms of L-dopa-induced dyskinesia: the findings, the debate, and the therapeutic implications. Front Neurol 5:242. https://doi.org/10.3389/fneur.2014.00242

Chanyachukul T, Yoovathaworn K, Thongsaard W, Chongthammakun S, Navasumrit P, Satayavivad J (2004) Attenuation of paraquat-induced motor behavior and neurochemical disturbances by L-valine in vivo. Toxicol Lett 150:259-269. https://doi.org/10.1016/j.toxlet.2004.02.007

Chau KY, Cooper JM, Schapira AHV (2010) Rasagiline protects against alphasynuclein induced sensitivity to oxidative stress in dopaminergic cells. Neurochem Int 57:525-529. https://doi.org/10.1016/j.neuint.2010.06. 017

Cho BH, Choi SM, Kim JT, Kim BC (2018) Association of coffee consumption and non-motor symptoms in drug-naive, early-stage Parkinson's disease. Parkinsonism Relat Disord 50:42-47. https://doi.org/10.1016/j.parkreldis. 2018.02.016

Colle D, Farina M (2021) Oxidative stress in paraquat-induced damage to nervous tissues. In: Toxicology. Elsevier, pp 69-78. https://doi.org/10.1016/ B978-0-12-819092-0.00008-X

Costa MS, Botton PH, Mioranzza S, Ardais AP, Moreira JD, Souza DO, Porciuncula LO (2008) Caffeine improves adult mice performance in the object recognition task and increases BDNF and TrkB independent on phosphoCREB immunocontent in the hippocampus. Neurochem Int 53:89-94. https://doi.org/10.1016/j.neuint.2008.06.006

De Deurwaerdère P, Di Giovanni G, Millan MJ (2017) Expanding the repertoire of L-Dopa's actions: a comprehensive review of its functional neurochemistry. Prog Neurobiol 151:57-100. https://doi.org/10.1016/j.pneurobio. 2016.07.002

Drury RA, Wallington EA, Cancerson R (eds) (1976) Carlton's histopathological techniques, 4th edn. Oxford University Press, Oxford

Fathalla AM, Soliman AM, Moustafa AA (2017) Selective A2A receptors blockade reduces degeneration of substantia nigra dopamine neurons in a rotenone-induced rat model of Parkinson's disease: a histological study. Neurosci Lett 643:89-96. https://doi.org/10.1016/j.neulet.2017.02.036

Finberg JP, Youdim MB (2002) Pharmacological properties of the anti-Parkinson drug rasagiline; modification of endogenous brain amines, reserpine reversal, serotonergic and dopaminergic behaviours. Neuropharmacology 43:1110-1118. https://doi.org/10.1016/s0028-3908(02)00216-2

Ghosh P, Boruah N, Sharma H (2018) Brain and bone delivery of drugs: a review on various techniques of drug delivery. Egypt Pharm J 17:141-149. https://doi.org/10.4103/epj.epj_21_18

Gonzalez-Polo RA, Rodriguez-Martin A, Moran JM, Niso M, Soler G, Fuentes JM (2004) Paraquat-induced apoptotic cell death in cerebellar granule cells. Brain Res 1011:170-176. https://doi.org/10.1016/j.brainres.2004.02.078

Goshima Y, Masukawa D, Kasahara Y, Hashimoto T, Aladeokin AC (2019) L-Dopa and its receptor GPR143: implications for pathogenesis and therapy in 
Parkinson's disease. Front Pharmacol 10:1119. https://doi.org/10.3389/ fphar.2019.01119

Gupta SP, Patel S, Yadav S, Singh AK, Singh S, Singh MP (2010) Involvement of nitric oxide in maneb- and paraquat-induced Parkinson's disease phenotype in mouse: Is there any link with lipid peroxidation? Neurochem Res 35:1206-1213. https://doi.org/10.1007/s1 1064-010-0176-5

Hirao K, Pontone GM, Smith GS (2015) Molecular imaging of neuropsychiatric symptoms in Alzheimer's and Parkinson's disease. Neurosci Biobehav Rev 49:157-170. https://doi.org/10.1016/j.neubiorev.2014.11.010

Hong CT, Chan L, Bai CH (2020) The effect of caffeine on the risk and progression of Parkinson's Disease: a meta-analysis. Nutrients. https://doi.org/10 3390/nu12061860

Ighodaro OM, Akinloye OA (2018) First line defence antioxidants-superoxide dismutase (SOD), catalase (CAT) and glutathione peroxidase (GPX): Their fundamental role in the entire antioxidant defence grid. Alex J Med 54:287-293. https://doi.org/10.1016/j.ajme.2017.09.001

Ikawa M, Okazawa H, Nakamoto Y, Yoneda M (2020) PET imaging for oxidative stress in neurodegenerative disorders associated with mitochondrial dysfunction. Antioxidants. https://doi.org/10.3390/antiox9090861

Ikram M et al (2019) Natural dietary supplementation of curcumin protects mice brains against ethanol-induced oxidative stress-mediated neurodegeneration and memory impairment via Nrf2/TLR4/RAGE signaling. Nutrients. https://doi.org/10.3390/nu1 1051082

Ikram M, Park TJ, Ali T, Kim MO (2020) Antioxidant and neuroprotective effects of caffeine against Alzheimer's and Parkinson's disease: insight into the role of Nrf-2 and A2AR signaling. Antioxidants. https://doi.org/10.3390/ antiox9090902

Im JJ, Jeong H, Chung YA, Park JS, Heo Y, Oh JK, Song IU (2019) Neuroprotective effects of rasagiline in Parkinson's disease: a regional cerebral blood flow study. J Neuroimaging 29:707-711. https://doi.org/10.1111/jon. 12661

Kachroo A, Irizarry MC, Schwarzschild MA (2010) Caffeine protects against combined paraquat and maneb-induced dopaminergic neuron degeneration. Exp Neurol 223:657-661. https://doi.org/10.1016/j.expneurol. 2010.02.007

Khan A, Ikram M, Muhammad T, Park J, Kim MO (2019) Caffeine modulates cadmium-induced oxidative stress, neuroinflammation, and cognitive impairments by regulating Nrf-2/HO-1 In Vivo And In Vitro. J Clin Med. https://doi.org/10.3390/jcm8050680

Kolahdouzan M, Hamadeh MJ (2017) The neuroprotective effects of caffeine in neurodegenerative diseases. CNS Neurosci Ther 23:272-290. https://doi. org/10.1111/cns. 12684

Kunchok A, Zekeridou A, McKeon A (2019) Autoimmune glial fibrillary acidic protein astrocytopathy. Curr Opin Neurol 32:452-458. https://doi.org/10. 1097/WCO.0000000000000676

Li L, Stary CM (2016) Targeting glial mitochondrial function for protection from cerebral ischemia: relevance, mechanisms, and the role of MicroRNAs. Oxid Med Cell Longev 2016:6032306. https://doi.org/10.1155/2016/ 6032306

Li D, Liu X, Liu T, Liu H, Tong L, Jia S, Wang YF (2020) Neurochemical regulation of the expression and function of glial fibrillary acidic protein in astrocytes. Glia 68:878-897. https://doi.org/10.1002/glia.23734

Liou HH, Chen RC, Tsai YF, Chen WP, Chang YC, Tsai MC (1996) Effects of paraquat on the substantia nigra of the wistar rats: neurochemical, histological, and behavioral studies. Toxicol Appl Pharmacol 137:34-41. https:// doi.org/10.1006/taap.1996.0054

Liu X et al (2016) The effect of A2A receptor antagonist on microglial activation in experimental glaucoma. Invest Ophthalmol Vis Sci 57:776-786. https://doi.org/10.1167/iovs.15-18024

Machado DG, Lara MVS, Dobler PB, Almeida RF, Porciúncula LO (2020) Caffeine prevents neurodegeneration and behavioral alterations in a mice model of agitated depression. Prog Neuropsychopharmacol Biol Psychiatry 98:109776. https://doi.org/10.1016/j.pnpbp.2019.109776

Maruyama W, Akao Y, Youdim MB, Naoi M (2000) Neurotoxins induce apoptosis in dopamine neurons: protection by $\mathrm{N}$-propargylamine-1(R)- and (S)aminoindan, rasagiline and TV1022. J Neural Transm Suppl. https://doi. org/10.1007/978-3-7091-6301-6_11

McCormack AL, Di Monte DA (2003) Effects of L-dopa and other amino acids against paraquat-induced nigrostriatal degeneration. J Neurochem 85:82-86. https://doi.org/10.1046/j.1471-4159.2003.01621.x
McCormack AL, Thiruchelvam M, Manning-Bog AB, Thiffault C, Langston JW, Cory-Slechta DA, Di Monte DA (2002) Environmental risk factors and Parkinson's disease: selective degeneration of nigral dopaminergic neurons caused by the herbicide paraquat. Neurobiol Dis 10:119-127. https://doi. org/10.1006/nbdi.2002.0507

Moccia M et al (2016) Caffeine consumption and the 4-year progression of de novo Parkinson's disease. Parkinsonism Relat Disord 32:116-119. https:// doi.org/10.1016/j.parkreldis.2016.08.005

Moran JM, Ortiz-Ortiz MA, Ruiz-Mesa LM, Fuentes JM (2010) Nitric oxide in paraquat-mediated toxicity: a review. J Biochem Mol Toxicol 24:402-409. https://doi.org/10.1002/jbt.20348

Nakaso K, Ito S, Nakashima K (2008) Caffeine activates the PI3KJAkt pathway and prevents apoptotic cell death in a Parkinson's disease model of SHSY5Y cells. Neurosci Lett 432:146-150. https://doi.org/10.1016/j.neulet. 2007.12.034

Naylor JL, Widdowson PS, Simpson MG, Farnworth M, Ellis MK, Lock EA (1995) Further evidence that the blood/brain barrier impedes paraquat entry into the brain. Hum Exp Toxicol 14:587-594. https://doi.org/10.1177/ 096032719501400706

Nuhu AA (2014) Bioactive micronutrients in coffee: recent analytical approaches for characterization and quantification. ISRN Nutrition 2014:384230. https://doi.org/10.1155/2014/384230

Oertel WH (2017) Recent advances in treating Parkinson's disease. F1000Research 6:260. https://doi.org/10.12688/f1000research.10100.1

Olanow CW, Stern MB, Sethi K (2009) The scientific and clinical basis for the treatment of Parkinson disease (2009). Neurology 72:S1-136. https://doi. org/10.1212/WNL.0b013e3181a1d44c

Parkinson Study Group (2002) A controlled trial of rasagiline in early Parkinson Disease: the TEMPO study. Arch Neurol 59:1937-1943. https://doi.org/10. 1001/archneur.59.12.1937

Pierri M, Vaudano E, Sager T, Englund U (2005) KW-6002 protects from MPTP induced dopaminergic toxicity in the mouse. Neuropharmacology 48:517-524. https://doi.org/10.1016/j.neuropharm.2004.11.009

Pires AO, Teixeira FG, Mendes-Pinheiro B, Serra SC, Sousa N, Salgado AJ (2017) Old and new challenges in Parkinson's disease therapeutics. Prog Neurobiol 156:69-89. https://doi.org/10.1016/j.pneurobio.2017.04.006

Poewe W et al (2017) Parkinson disease. Nat Rev Dis Primers 3:17013. https:// doi.org/10.1038/nrdp.2017.13

Rabey JM et al (2000) Rasagiline mesylate, a new MAO-B inhibitor for the treatment of Parkinson's disease: a double-blind study as adjunctive therapy to levodopa. Clin Neuropharmacol 23:324-330

Rai SN, Singh P (2020) Advancement in the modelling and therapeutics of Parkinson's disease. J Chem Neuroanat 104:101752. https://doi.org/10. 1016/j.jchemneu.2020.101752

Rascol O, Perez-Lloret S, Ferreira JJ (2015) New treatments for levodopainduced motor complications. Move Disord 30:1451-1460. https://doi. org/10.1002/mds.26362

Ross GW et al (2000) Association of coffee and caffeine intake with the risk of Parkinson disease. JAMA 283:2674-2679. https://doi.org/10.1001/jama. 283.20.2674

Rozas G, Guerra M, Labandeira-García J (1997) An automated rotarod method for quantitative drug-free evaluation of overall motor deficits in rat models of parkinsonism. Brain Res Protoc 2:75-84. https://doi.org/10.1016/ s1385-299x(97)00034-2

Sagi Y, Mandel S, Amit T, Youdim MB (2007) Activation of tyrosine kinase receptor signaling pathway by rasagiline facilitates neurorescue and restoration of nigrostriatal dopamine neurons in post-MPTP-induced parkinsonism. Neurobiol Dis 25:35-44. https://doi.org/10.1016/..nbd.2006.07.020

Sarkar S et al (2017) Mitochondrial impairment in microglia amplifies NLRP3 inflammasome proinflammatory signaling in cell culture and animal models of Parkinson's disease. NPJ Parkinson's Dis 3:30. https://doi.org/10. 1038/s41531-017-0032-2

Schiffmann SN, Fisone G, Moresco R, Cunha RA, Ferre S (2007) Adenosine A2A receptors and basal ganglia physiology. Prog Neurobiol 83:277-292. https://doi.org/10.1016/j.pneurobio.2007.05.001

Shimizu K et al (2001) Carrier-mediated processes in blood-brain barrier penetration and neural uptake of paraquat. Brain Res 906:135-142. https:// doi.org/10.1016/s0006-8993(01)02577-x

Shin JY, Park HJ, Ahn YH, Lee PH (2009) Neuroprotective effect of L-dopa on dopaminergic neurons is comparable to pramipexol in MPTP-treated animal model of Parkinson's disease: a direct comparison study. J 
Neurochem 111:1042-1050. https://doi.org/10.1111/j.1471-4159.2009. 06381.x

Simola N, Pinna A, Frau L, Morelli M (2014) Protective agents in Parkinson's disease: caffeine and adenosine A2A receptor antagonists. In: Kostrzewa RM (ed) Handbook of neurotoxicity. Springer, New York, pp 2281-2298. https://doi.org/10.1007/978-1-4614-5836-4_103

Singhal NK, Srivastava G, Patel DK, Jain SK, Singh MP (2011) Melatonin or silymarin reduces maneb- and paraquat-induced Parkinson's disease phenotype in the mouse. J Pineal Res 50:97-109. https://doi.org/10. 1111/j.1600-079X.2010.00819.x

Soliman AM, Fathalla AM, Moustafa AA (2016) Dose-dependent neuroprotective effect of caffeine on a rotenone-induced rat model of parkinsonism: a histological study. Neurosci Lett 623:63-70. https://doi.org/10.1016/j. neulet.2016.04.057

Stocchi F, Fossati C, Torti M (2015) Rasagiline for the treatment of Parkinson's disease: an update. Expert Opin Pharmacother 16:2231-2241. https://doi. org/10.1517/14656566.2015.1086748

Sun M, Zigman S (1978) An improved spectrophotometric assay for superoxide dismutase based on epinephrine autoxidation. Anal Biochem 90:81-89. https://doi.org/10.1016/0003-2697(78)90010-6

Trudler D, Weinreb O, Mandel SA, Youdim MB, Frenkel D (2014) DJ-1 deficiency triggers microglia sensitivity to dopamine toward a pro-inflammatory phenotype that is attenuated by rasagiline. J Neurochem 129:434-447. https://doi.org/10.1111/jnc.12633

Ugusman AB, Riddell A, Kennedy S (2019) Effect of peroxynitrite (ONOO-) on the function of murine perivascular adipose tissue. Pharmacol Pharm 10:194-204. https://doi.org/10.4236/pp.2019.104017

Ullrich S, de Vries YC, Kuhn S, Repantis D, Dresler M, Ohla K (2015) Feeling smart: effects of caffeine and glucose on cognition, mood and selfjudgment. Physiol Behav 151:629-637. https://doi.org/10.1016/j.physbeh. 2015.08 .028

Voon V et al (2017) Impulse control disorders and levodopa-induced dyskinesias in Parkinson's disease: an update. Lancet Neurol 16:238-250. https:// doi.org/10.1016/S1474-4422(17)30004-2

Wasserman B, Block ER (1978) Prevention of acute paraquat toxicity in rats by superoxide dismutase. Aviat Space Environ Med 49:805-809

Weinreb O, Badinter F, Amit T, Bar-Am O, Youdim MB (2015) Effect of long-term treatment with rasagiline on cognitive deficits and related molecular cascades in aged mice. Neurobiol Aging 36:2628-2636. https://doi.org/ 10.1016/j.neurobiolaging.2015.05.009

Widdowson PS, Farnworth MJ, Simpson MG, Lock EA (1996) Influence of age on the passage of paraquat through the blood-brain barrier in rats: a distribution and pathological examination. Hum Exp Toxicol 15:231-236. https://doi.org/10.1177/096032719601500308

Wills AM et al (2013) Caffeine consumption and risk of dyskinesia in CALM-PD. Move Disord 28:380-383. https://doi.org/10.1002/mds.25319

Xu K, Bastia E, Schwarzschild M (2005) Therapeutic potential of adenosine A(2A) receptor antagonists in Parkinson's disease. Pharmacol Ther 105:267-310. https://doi.org/10.1016/.jpharmthera.2004.10.007

Xu K, Xu YH, Chen JF, Schwarzschild MA (2010) Neuroprotection by caffeine: time course and role of its metabolites in the MPTP model of Parkinson's disease. Neuroscience 167:475-481. https://doi.org/10.1016/j.neuroscien ce.2010.02.020

Yagi K (1998) Simple procedure for specific assay of lipid hydroperoxides in serum or plasma. Methods Mol Biol 108:107-110. https://doi.org/10. 1385/0-89603-472-0:107

Zeinvand-Lorestani H, Nili-Ahmadabadi A, Balak F, Hasanzadeh G, Sabzevari O (2018) Protective role of thymoquinone against paraquat-induced hepatotoxicity in mice. Pestic Biochem Physiol 148:16-21. https://doi.org/ 10.1016/j.pestbp.2018.03.006

Zhang L, Dawson VL, Dawson TM (2006) Role of nitric oxide in Parkinson's disease. Pharmacol Ther 109:33-41. https://doi.org/10.1016/j.pharmthera. 2005.05.007

Zhang XF, Thompson M, Xu YH (2016) Multifactorial theory applied to the neurotoxicity of paraquat and paraquat-induced mechanisms of developing Parkinson's disease. Lab Investig 96:496-507. https://doi.org/10.1038/ labinvest.2015.161

\section{Publisher's Note}

Springer Nature remains neutral with regard to jurisdictional claims in published maps and institutional affiliations.

\section{Submit your manuscript to a SpringerOpen ${ }^{\circ}$ journal and benefit from:}

- Convenient online submission

- Rigorous peer review

- Open access: articles freely available online

- High visibility within the field

- Retaining the copyright to your article

Submit your next manuscript at $\boldsymbol{\nabla}$ springeropen.com 